\title{
Roundwood and Biomass Logistics in Finland and Sweden
}

\author{
Kari Väätäinen, Perttu Anttila, Lars Eliasson, Johanna Enström, Juha Laitila, \\ Robert Prinz, Johanna Routa
}

\begin{abstract}
Logistics of roundwood and biomass comprise a high number of operations, machinery, storage sites and transportable roundwood and biomass assortments. Moreover, complex and highly varying operational environment through the year poses logistics challenges incurring additional costs. An extensive review of studies was conducted in Sweden and Finland concerning roundwood and biomass logistics, starting from roadside landings and ending with delivery to a mill or a conversion facility. The main aim of the review was to describe trends in roundwood and biomass logistics since the start of the century. Papers were classified to categories of truck transports and roads, terminals, multimodal transports, storage and supply chain logistics. Slightly over $50 \%$ of reviewed articles were constrained to biomass only, 31\% to roundwood only and $14 \%$ to both. Rapid technology development, amendments concerning road transports, increasing environmental concerns and forestry sector's push to decrease the logistics costs can be seen as the biggest drivers for the reviewed studies and their study objectives. These aspects will also drive and increase the demand for research and development in roundwood and biomass logistics in the future.
\end{abstract}

Keywords: transportation, trucking, supply chain, timber, energy wood, terminal, railway, waterway, multimodal transport

\section{Introduction}

\subsection{Roundwood and Biomass Production and Harvesting}

The forest industry in Sweden and Finland uses both mechanical and chemical processing of wood. The countries are two of the world's largest exporters of pulp, paper and cardboard, and among Europe's largest producers of sawn timber and plywood (Metsätilastollinen vuosikirja 2014, Skogsstatistisk årsbok 2014). The forest industry has a broad influence on society, and the forest cluster is the main source of income for many regions (Avain Suomen metsäteollisuuteen 2004, Forests and Forestry in Sweden 2015). In 2017, roundwood consumption in forest industries was 69.7 million $\mathrm{m}^{3}$ in Finland (OSF) and 85.6 million $\mathrm{m}^{3}$ in Sweden (Ylitalo 2018, Swedish Forest Agency 2019).
The management of commercial forests in Finland and Sweden is predominantly based on even-aged forestry, with a typical rotation period of 60-80 years from regeneration to felling (Avain Suomen metsäteollisuuteen 2004, Forests and Forestry in Sweden 2015). During the rotation period, forest sites are managed with repeated intermediate cutting (i.e. selective thinning), whereby trees of little economic value or poor quality, and the smallest trees, are removed to meet the targeted tree density and thickness (Avain Suomen metsäteollisuuteen 2004, Forests and Forestry in Sweden 2015). The aim of silviculture is to maximise the yield of the most valuable roundwood assortments in the forest.

In Sweden and Finland, logging is based on the cut-to-length (CTL) method, both in thinning and regeneration cutting (Avain Suomen metsäteollisuuteen 2004, Forests and Forestry in Sweden 2015). In the CTL 
method, the stem is both delimbed and crosscut into multiple wood assortments on the site with a singlegrip harvester. Immediately after cutting, wood assortments (saw timber, pulp and energy assortments) are transported by a forwarder to the roadside landing. Here, logs and biomass are piled in different assortments and temporarily stored before road transport to the end-use facility or terminal (Avain Suomen metsäteollisuuteen 2004, Forests and Forestry in Sweden 2015).

To qualify as sawlogs, tree sections must be sufficiently straight and thick, which is why sawlogs are generally harvested at the end of the rotation period. Sawlog assortments are further processed into various wood products such as boards, balks, plywood and planks (Avain Suomen metsäteollisuuteen 2004, Forests and Forestry in Sweden 2015). Stems and stem sections with smaller diameters and/or lower quality than sawlogs are cross-cut as pulpwood assortments, which are harvested mainly by thinning. Pulpwood is processed at pulp mills before use in the production of paper and cardboard (Avain Suomen metsäteollisuuteen 2004, Forests and Forestry in Sweden 2015). By-products of sawmills and plywood mills (wood chips and saw dust) are either used for pulping, chipboard manufacture, or in heat and power generation.

Cutting of roundwood also creates residues - tops, branches, non-merchantable roundwood, small-diameter trees, and stumps. An increasing proportion of this forest raw material is collected, chipped, and incinerated to generate energy in heat and power plants, as a substitute for fossil fuels (Avain Suomen metsäteollisuuteen 2004, Forests and Forestry in Sweden 2015). The consumption of forest industry by-products (e.g. bark and sawdust) and wood residues for heat and energy production in 2018 was 11.4 million $\mathrm{m}^{3}$ in Finland, and the consumption of forest chips was 7.4 million $\mathrm{m}^{3}$ in Finland (OSF) and 7.6 million $\mathrm{m}^{3}$ in Sweden (Wood in energy generation 2019, Swedish Energy Agency 2019).

In Finland, $60 \%$ of forest land is privately owned, while in Sweden the figure is slightly smaller (50\%) (Ihalainen and Vaahtera 2018, Swedish Forest Agency 2019). The high proportion of private ownership of forests means that woodlots are rather small, and the great variation in soil bearing conditions and stage in forest development means that logging sites can also be relatively small. Depending on the standing volume of the site and the cutting type (pre-commercial thinning, first thinning, second thinning, final felling), the extraction from each harvesting site varies typically from 50 to $1500 \mathrm{~m}^{3}$, averaging $400-600 \mathrm{~m}^{3}$ in Finland (Jylhä et al. 2019). The number of wood assortments cut from harvesting sites can vary between one and 16 (Jylhä et al. 2019), depending on the number of tree species, the size and quality of trees and the sales agreement. The scattered roadside landings, together with the large number of timber assortments and varying volumes, have a strong impact on supply logistics (i.e. logistical efficiency and management) from landings to end-use facilities (e.g. Uusitalo 2005, Nurminen and Heinonen 2007).

\subsection{Roundwood and Biomass Supply Logistics in a Nordic Context}

The term »logistics « derives from the military and war domain. According to the glossary prepared by the Council of Supply Chain Management Professionals

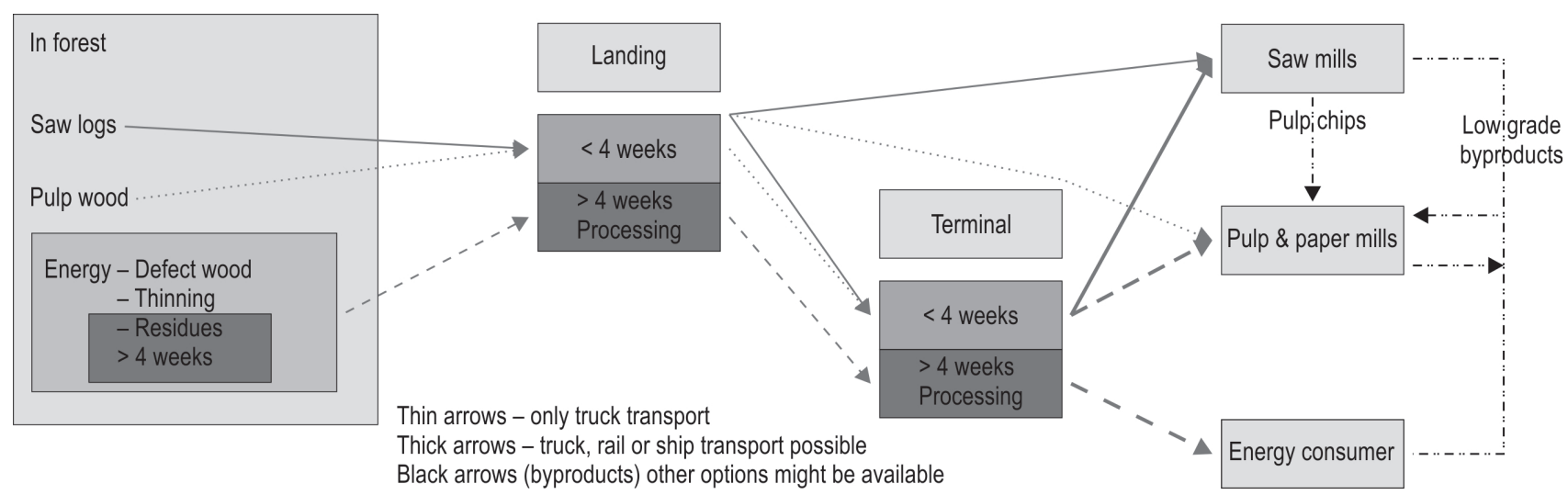

Fig. 1 A generalised view of the supply chain for forest biomass, from stump to end-use facility. Sawlog and pulpwood flows are characterised by relatively short storage times in the forest and at landings and terminals as the customers demand fresh wood. However, during sub-zero temperatures storage times can increase at landings and terminals. Supply of energy wood, on the other hand involves more and longer storage of material at all nodes in the supply chain 
(CSCMP 2019), »Logistics and logistics management is the part of the supply chain management that plans, implements, and controls the efficient, effective forward and reverse flow and storage of goods, services and related information between the point of origin and the point of consumption in order to meet the customers' requirements." The main activities in logistics management involve inbound and outbound transportation management, fleet management, warehousing, materials handling, order fulfilment, logistics network design, inventory management, supply/demand planning, and management of third-party logistics service providers (CSCMP 2019).

Broadly speaking, supply logistics for roundwood and biomass start when the trees are felled and processed to logs according to customer specifications regarding dimension and quality, and end when the product is delivered to the customer (Fig. 1). The harvesting activity is dictated by the demand for sawlogs and pulpwood in the forest industry, stumpage prices of timber, forest owners' willingness to sell timber, logging conditions (e.g. thaw and wet seasons), and thinning needs. Biomass for energy is typically a byproduct of final felling, except when it is collected from early thinning. The demand for industrial roundwood is relatively constant throughout the year, except for a dip in sawmill production during the summer vacation period (Venäläinen et al. 2017a). In contrast, the demand for biomass for energy is seasonal, and strongly dependent on the temperature (Gadd and Werner 2013).

Short lead time for timber is important in the supply chain of industrial roundwood, mainly due to the need to maintain timber quality (i.e. added value potential) and minimise the capital tied up in purchased timber (Venäläinen et al. 2017a). However, difficulties in accessing logging sites during the season when roads are in a poor state and low bearing capacity of forest soil (i.e. terrain trafficability) during thaw and rainy periods, particularly at sensitive sites, causes variation in timber procurement and supply. Consequently, roundwood must be stored for longer, to ensure a constant supply of wood to industry. This increases logging volumes during winter and timber transports during late winter, when timber is transported from landings on roads with poor trafficability to intermediate storage (i.e. terminals) next to betterquality roads. For energy assortments, wood storage is necessary to meet the seasonal demand for biomass. Storage also provides an opportunity to reduce moisture content, thereby increasing the value of the biomass and improving transport efficiency. In the Nordic region, seasonality in forest biomass harvesting presents additional and specific challenges to the supply logistics.

Although forest biomass supply chains use various modes of transportation, all biomass on the landings is transported by truck, either directly to the mill or to a terminal for storage and/or reloading to rail or waterborne transport. The primary characteristics of biomass transport by truck in Sweden and Finland are:

$\Rightarrow$ the continuously changing starting point of transport, with varying numbers and amounts of wood assortments

$\Rightarrow$ the dense network of small forest roads and private roads with varying degrees of trafficability

$\Rightarrow$ public roads with good trafficability and better road maintenance (e.g. Malinen et al. 2014).

The number of roadside landings is high - in 2016, roundwood and energy biomass was collected from about 244,000 unique landings in Sweden (Davidsson and Asmoarp 2019). Rules and regulations applying to both private and public roads also affect transport, and may restrict truck transports at certain times of the year. Terminals are used to secure wood supply, but come with the additional costs of establishment, extra handling of stored material, and longer total transport distance. Another aspect is that cost- and energy-efficient long-distance transport methods are vital because of the large procurement areas of the forest industry and distant location of parts of the feedstock.

In the Nordic context, three supply chain modes dominate, both for industrial roundwood and biomass for energy:

$\Rightarrow$ direct transport by trucks

$\Rightarrow$ transport by trucks via terminal

$\Rightarrow$ transport using multimodal transport methods, using trucks for inbound logistics and railways or waterways for outbound logistics.

Supply modes for energy biomass can be even more numerous, according to the type and form of biomass during transport, and/or by the timing and positioning of comminution in the supply chain. Consequently, there can be more different supply chain types for energy biomass than for industrial roundwood.

At the start of the century, timber trucks with a maximum gross vehicle weight (GVW) of $60 \mathrm{t}$ and a length of 24 metres (25.25 if EU-modules were used) were permitted on most roads in Sweden and Finland (Anttila et al. 2012). To attain this GVW, most vehicles consisted of a 3-axle lorry with a 4-axle trailer, to comply with the statutory limits for maximum axle loads. Vehicles for timber transport were configured in either of the two ways: 
$\Rightarrow$ trucks equipped with a removable grapple loader, so that the vehicle itself could load and unload the timber on the landing

$\Rightarrow$ trucks not equipped with a loader, requiring a separate loader-truck for loading on the landing (only in Sweden).

The first solution offers flexibility to logistics, enabling load to be added from multiple landings during the load cycle. The second solution is preferred if transport distances are long, if several trucks are transporting timber from the selected landing, and/or harvesting volumes from logging sites are large. The absence of a grapple loader allows bigger payloads, and loading is faster with the separate loader. Although these two configurations are still standard, alternative truck transport concepts have been evaluated (e.g. exchangable load platforms) (Kuitto and Rajala 1982, Asikainen 1995).

Vehicles transporting forest biomass are less standardised, but can be classified into four groups:

$\Rightarrow$ roundwood trucks equipped with side plates for transporting tree sections

$\Rightarrow$ vehicles for loose-residue transport with steel vans and a large grapple loader to load and compress the material (Norden 1992). Due to their high unladen vehicle weight, these vehicles have a comparatively low payload

$\Rightarrow$ chip trucks with fixed containers on a tractor and a trailer. These trucks need to be loaded by either the chipper/crusher or a separate loader, but can have a relatively high payload

$\Rightarrow$ interchangeable container trucks for chips. By using a buffer of three to six containers on the landing, these trucks are not as sensitive to interactions with the chipper, and loading times can be reduced. However, unladen vehicle weight is higher than for the chip trucks with fixed containers, so payloads are smaller.

\subsection{Key Drivers and Challenges in Developing Roundwood and Biomass Logistics}

Roundwood and biomass transport and logistics is constantly evolving, due to rapid technological advances, tough global competition in end-product markets and the pressure to reduce environmental impacts. In Sweden and Finland, new legislation relating to vehicle weights and spatial dimensions of trucks in road transport has led to upgrades in the transport fleets operating on roads today. In addition, High Capacity Transport (HCT) vehicles for forest transports, exceeding the country-specific limits for maximum GVWs and dimensions at the time of the tests, have been tested in both Finland and Sweden (Asmoarp et al. 2018, Venäläinen and Poikela 2019). HCT vehicles henceforth refers to vehicles with a GVW exceeding 60 tonnes, as this was the maximum GVW in 2010 in both countries. International and national regulations and agreements relating to the climate and greenhouse gas (GHG) emissions have increased the importance of developing transport and logistics solutions with greater energy efficiency and lower exhaust emissions. This has increased interest in multimodal transport solutions where feasible.

Due to the greater availability, accuracy and detail of data, as well as development of IT systems using the data, forest biomass logistics systems can now be controlled and managed with greater precision and efficiency. In recent years, a lot of software has been developed for controlling and managing biomass supply logistics. Solutions for open-sourced, multi-client and/or contractor-focused fleets, workshift and storage management systems are now used widely in Finland and Sweden for industrial roundwood.

Storms, wildfires and insects sometimes cause major disturbances in the forest production system. For example, the current situation in Central Europe with spruce bark beetle is very serious in many regions. However, major disturbances occur frequently even under normal conditions, and the production system must be flexible enough to handle them. Forest fuel products have high seasonal fluctuations due to the shifting demand in heat production, which causes inefficiencies such as low annual machine utilisation rates, and presents challenges to contractors in forest fuel production.

\subsection{Objectives of the Study}

A number of review articles on roundwood and biomass logistics have been published in recent years (Routa et al. 2013, Wolfsmayr and Rauch 2014, Ghaffariyan et al. 2017, Erber and Kühmaier 2017, Kogler and Rauch 2018, Koirala et al. 2018, Kühmaier and Erber 2018, Malladi and Sowlati 2018, Acuna et al. 2019, Spinelli et al. 2019). However, there has been no review of studies focusing on the Nordic countries, where supply is characterised by high volumes and long distances. Much of the research is available only in local languages, which further highlights the demand for a review in English.

The main aim of this review was to describe trends in roundwood and biomass logistics with a special focus on transportation, terminals and storage in Finland and Sweden since the start of the century, and to set this in an international perspective. Some key issues relating to the structure and behaviour of the logistics system are discussed in connection with the results. 


\section{Materials and Methods}

The review gives a general overview of biomass logistics in Sweden and Finland, including the dominant supply chain types and proportions of operational volumes. It identifies the trends in these supply chains since the turn of the century. The review also highlights the role of legislation and regulation, which has a distinct impact on biomass logistics. The focus is then widened into the building blocks of biomass logistics, defined as:

$\Rightarrow$ truck transport and roads

$\Rightarrow$ terminal concepts and terminal logistics

$\Rightarrow$ storage of wood

$\Rightarrow$ multimodal transport

$\Rightarrow$ supply chain logistics.

The fifth building block, supply chain logistics, presents an overview of research methods and key findings from some of the reviewed papers.

The work was limited to roundwood and forest biomass logistics, starting from roadside landings and ending with delivery to the mill or forest biomass refining and conversion facilities. Studies on roadside landing activities were not included, unless there was a connection with other logistics operations. Moreover, the analysis did not include biomass reception and log yard logistics, so in this review the logistic chain ends at the mill/facility gate.

Reviewed papers were categorised using the predefined result indicators: productivity, cost efficiency, resource utilisation, energy efficiency (i.e. fuel con- sumption, dry-matter losses, energy content), GHG emissions, social aspects, transport safety, payload efficiency, and roads.

The literature review focused on peer-reviewed articles (including doctoral theses) and non-reviewed publications. The latter were typically results of national $R \& D$ projects and were presented in local languages. Master's theses were not systematically reviewed. However, a small number of Master's theses were included in cases where these presented unpublished, important findings in the field of supply chain logistics. The article search was conducted in October - November 2019. However, several new articles were added during the review process until July 2020. Relevant publications were found using a combination of Google Scholar and snowball sampling through the literature of already selected articles. The main keywords used in the search were »biomass«, »timber «, »logistics «, »transport «, »terminal «, »roundwood «, »energy wood «, »supply chain«, and »trucking «. Sometimes, a combination of several keywords was used (e.g. »timber trucking Finland « or »truck transport timber Finland «). In addition, all the issues of the following report series since 2000 were systematically scanned for relevant reports:

$\Rightarrow$ Metsätehon tuloskalvosarja (http://www.metsateho.fi/kategoria/tuloskalvosarja/)

$\Rightarrow$ Metsätehon raportti (http://www.metsateho.fil kategoria/raportti/)

$\Rightarrow$ Skogforsk kunskapsbanken (https://www.skogforsk.se/kunskap/kunskapsbanken/)

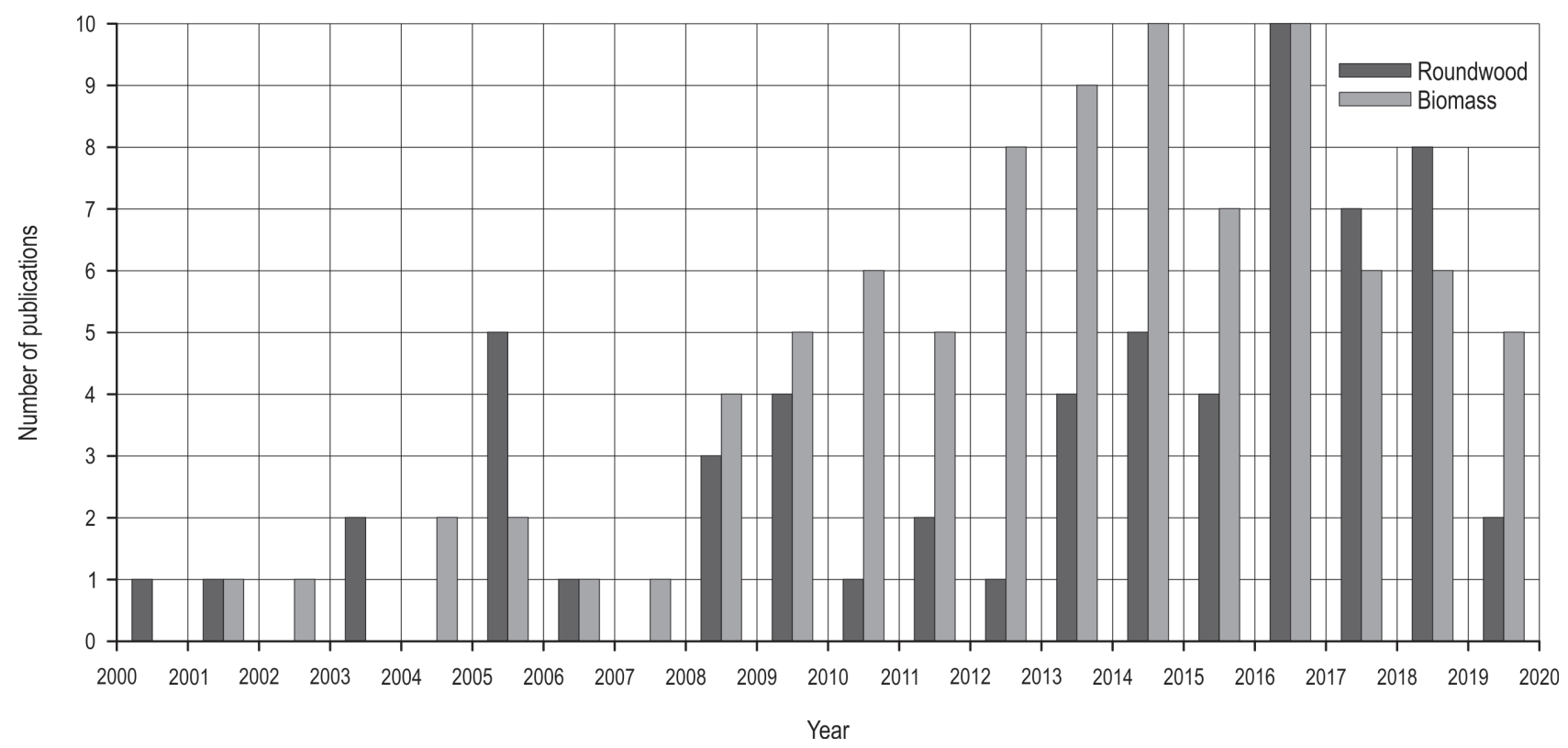

Fig. 2 Classification of reviewed papers according to publication year and assortment 


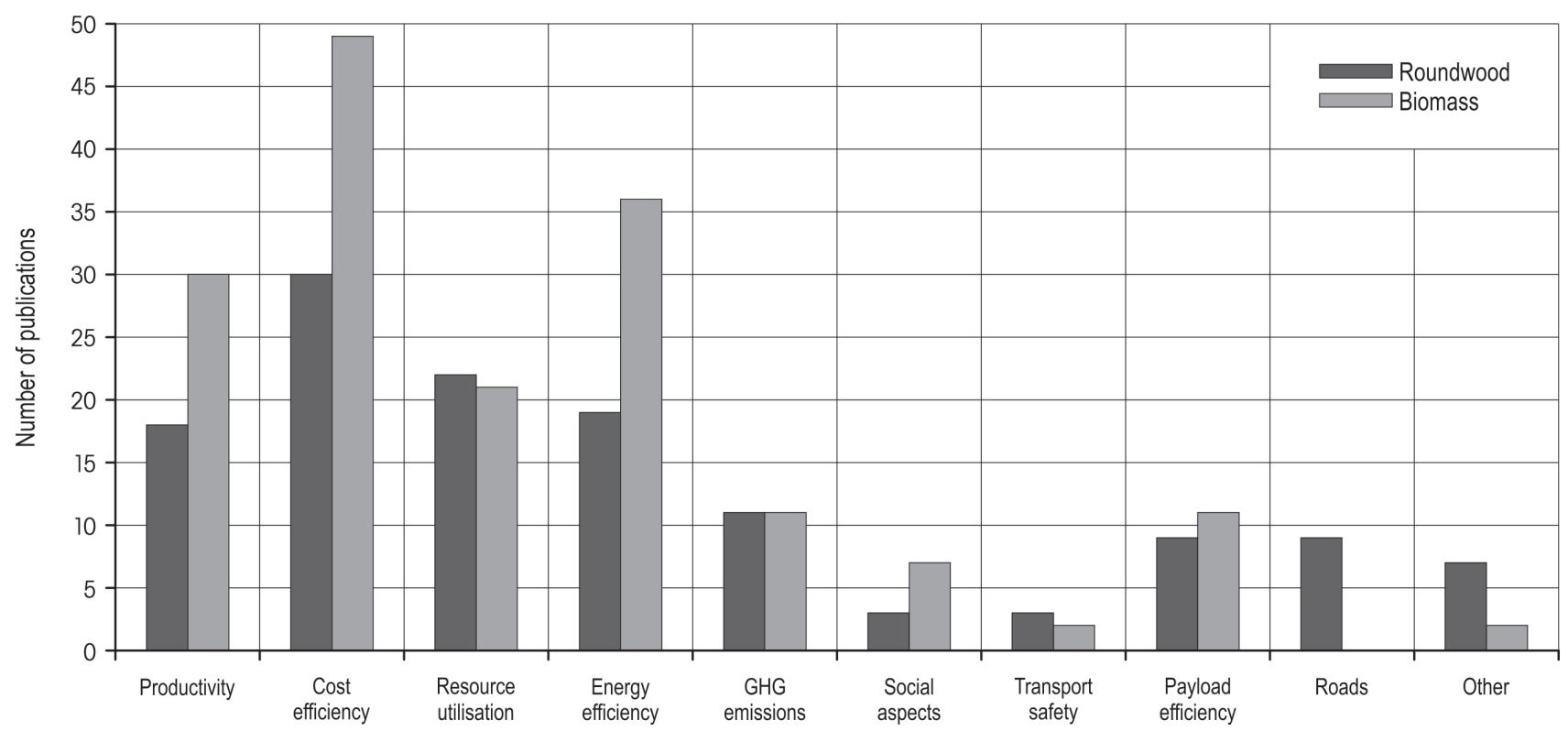

Fig. 3 Classification of reviewed papers according to pre-defined result indicators

Based on the search and the scan, the study material consisted of a total of 138 papers which are presented in chapters $3.3-3.7$. Of these, 86 were peerreviewed papers, 6 Master's theses and 46 other reports. In Fig. 2 the papers were classified according to publication year and assortment (roundwood/biomass). Slightly over half of the papers focused on biomass only, nearly one third on roundwood only and $14 \%$ on both. Two papers dealt solely with roads.

Cost efficiency, resource utilisation, energy efficiency and productivity were the most common topics in roundwood publications (Fig. 3). In biomass publications cost and energy efficiency and productivity gained most attention.

\section{Results}

\subsection{Changes in Legislation Affecting Round- wood and Biomass Logistics}

Legislation and policies with significant influence on the forestry logistics system include regulations on vehicle configuration and weights. In both Finland and Sweden, permitted vehicle dimensions and GVWs have been increased in recent years.

In Finland, the following limits to the physical dimensions of a truck-trailer combination were set in 2013: total vehicle length $25.25 \mathrm{~m}$, width $2.6 \mathrm{~m}$ and height $4.4 \mathrm{~m}$ (Valtioneuvoston asetus 407/2013). Since January 2019, the maximum permitted length of a truck has been $13 \mathrm{~m}$ (increased from $12 \mathrm{~m}$ ) and of a combination $34.5 \mathrm{~m}$ (Valtioneuvoston asetus 31/2019). The maximum GVW is $68 \mathrm{t}$ for an 8 -axle combination vehicle $(3+5$ or $4+4$ axles in truck and trailer respectively) and $76 \mathrm{t}$ for a 9-axle combination ( $4+5$ axles). The condition is that $65 \%$ of trailer axles must have twin tyres, otherwise the maximum weights are 64 and 69 t. Previously in Finland, the standard trucktrailer unit consisted of a three-axle truck and fouraxle trailer resulting in a $60 \mathrm{t}$ legal gross weight and $22 \mathrm{~m}$ total vehicle length (e.g. Nurminen and Heinonen 2007, Valtioneuvoston asetus 407/2013).

In Sweden, the maximum GVW was increased to $64 \mathrm{t}$ on most roads in 2015 and to $74 \mathrm{t}$ on selected roads in 2017 (Asmoarp et al. 2018). Maximum vehicle lengths, however, have not been changed and remain at $25.25 \mathrm{~m}$ for trucks using EU-modules or $24 \mathrm{~m}$ for the classic truck and 4-axle trailer (wagon) combinations (von Hofsten 2019).

After the deregulation of railway transport in Finland in 2007, it was anticipated that competition would emerge in timber transport by rail (Saranen 2009). However, the state railway company VR remains the only operator involved in the transport of roundwood. The administrative regulations in rail transport, especially lead times in applying for access, are limiting the flexibility of the system (Enström and Winberg 2009). The increased capacity in the rail system has not kept up with road transport developments, although some attempts have been made to increase length and total weight of trains in both Finland and Sweden (Vierth 2014, Venäläinen 2019). 
Regulations relating to forestry management and business agreements also influence the logistics system, for example by limiting the time during which fallen wood can be left in the forest or on roadside landings due to risk of insect outbreaks (Laki metsätuhojen torjunnasta 2013). Measurement of forest products (wood assortments) is regulated by law both in Sweden and Finland. Since 2013 and 2014, forest fuel assortments have been included in the legislation relating to measurements, regulating the accuracy of measurements, e.g. in the first stage of trade from the forest owner (Laki puutavaran mittauksesta 2013, Lag om virkesmätning 2014). This makes it necessary to accurately measure all forest products before material is stored at a terminal, since this is where the traceability of individual truck loads is usually lost.

\subsection{Supply Chains and Development Trends}

For truck transport, 3-4-axle tractors and 4-5-axle trailers dominate the transportation of wood supplying forest and energy industries in Finland and Sweden (Strandström 2018a, Strandström 2018b, von Hofsten 2019). In Finland in 2017, 75\% of the industrial roundwood transported was brought to the mill by road either directly or via terminals (Strandström 2018a). Forest chips are transported by chip trucks with solid frames or interchangeable container trucks to the power and heating plants; currently, only a few large CHP installations can use rail or water transportation.

A solid-frame truck-trailer vehicle is also the most commonly used system for the transport of by-product in the forest industry (Karttunen et al. 2012a, Laitila et al. 2016a). Comminution at terminals represents $33 \%$ of all forest chip supply volumes in Finland (Strandström $2018 \mathrm{~b})$. When storage of chips and uncomminuted material at terminals is added, forest chip supply via terminals is estimated at approximately $35-40 \%$ of all volumes. The supply of roundwood via terminals (i.e. intermediate storage) is not available in either Finland or Sweden, but the share of truck transports from terminals has increased in recent years.

Railways are the dominant transport method in Nordic in Sweden and Finland for long-distance transport of forest biomass. The average transport distance by rail in Finland in 2017 was 274 km (Strandström 2018a). The dominating system for rail transport in the Nordic countries is a unit train, which is a chartered train with full load for a specific customer, e.g. a forest company or a big energy producer (Orgård 1998). Railway transportation accounts for $23 \%$ of the total transported volume, and waterway transportation (by floating or barge) accounts for $2 \%$ (Strandström 2018a).
In Sweden about $15 \%$ of roundwood was transported by rail in 2014 (Svensson 2017).

In Finland, the proportion of logs floated along inland waterways has been decreasing steadily since the start of the century, and now represents less than 1\% of all transports, despite the high cost-efficiency of this method over long distances (Strandström 2018a, Venäläinen 2018). The volumes transported by barge have remained stable. Small amounts of domestic timber and forest fuel are transported by ship in the Gulf of Bothnia (e.g. Seppälä 2019). In Sweden, no wood is transported by inland waterway.

Comminution is a key part of the forest chip supply chain, taking place on the logging site, on the roadside landing, at a terminal, or at the plant (Hakkila 2004, Kärhä 2011, Eriksson et al. 2013, Routa et al. 2013). A system where wood is comminuted on the roadside landing is integrated with truck transportation, and can increase idling times for both the chipper and trucks (Asikainen 1995, Routa et al. 2013, Eriksson et al. 2013).

Both in Finland and in Sweden, comminuting on the roadside landing is the predominant practice in the supply system for logging residues from final fellings and small trees from thinning. In Finland in 2017, 54\% of forest chips were comminuted on roadside landings (Strandström 2018b). About 33\% of forest chips were produced at the terminals and $12 \%$ were comminuted at end-use facilities (Strandström 2018b). Comminuting in the terrain has ceased in Finland (Strandström 2018b). The conventional supply chain consists of one truck mounted chipper and two or three containerbased chip trucks with trailers (Routa et al. 2013). Comminuting at the terminal or at the end-use facility is the leading method for producing fuel chips from stumps or rotten non-merchantable roundwood, however the proportion of the chip production system based on comminuting at the end-use facility has decreased recently, mainly due to reduced bundling and stump harvesting volumes in Finland (Strandström 2018b).

In Sweden about $90 \%$ of the logging residues and small trees are comminuted on roadside landings, while most of the defect roundwood used for energy is comminuted at terminals (Brunberg 2014, 2016). For chipping on landings, the most commonly used systems are forwarder-mounted chippers in combination with container trucks or self-loading chip trucks, and chipper trucks (Brunberg 2016, Eliasson 2016). However, the supply systems for biomass are constantly evolving, and there is a need for more versatile systems that can handle the variation in demand (Eliasson 2016).

In Sweden, attempts have been made to find supply systems less prone to delays caused by machine interactions than is the case with the dominant system with 
a forwarder-mounted chipper and container trucks. One system introduced on a large scale is the chippertruck (Eliasson 2011a), which chips the residues and transports the chips to the customer. The advantages were the absence of interactions and the fact that the system is easy to manage. However, problems occurred with chipper-trucks catching fire and breaking down (Eliasson et al. 2016). When these events occur, chip supply to the customer is immediately shut down as there are no buffers in the system. Another option investigated was to break the interaction by allowing the chipper to pile chips on the landing and use a selfloading chip truck for transport (Liss 2006).

The drawback with the chipping at the roadside method is that it relies on road access to the roadside landing at the time when the demand of biomass for heat and energy is high, unless the chips are transported to a terminal for storage with the increased handling costs and a higher risk of degradation (see chapters 3.4 and 3.5). An obvious alternative is to transport the uncomminuted material to a terminal and chip it when needed using more efficient chippers compared to those used at roadside. As loose material is expensive to transport over long distances, compaction (bundling) of the material is beneficial to reduce the transport costs (Hakkila 2004). Large efforts have been made to develop efficient baling machines and supply systems for baling, chipping and transporting logging residues and small trees in Finland (Laitila et al. 2009, Kärhä and Vartiamäki 2006, Kärhä et al. 2011, Laitila et al. 2013, Nuutinen and Björnheden 2016, Nuutinen et al. 2016), Sweden (Lindroos et al. 2010, Eliasson 2011b) and elsewhere in Europe (Spinelli and Magagnotti 2009, Spinelli et al. 2012, Sánchez-Garcia et al. 2015). However, in Sweden the baling of logging residues was found to be too costly to be competitive against roadside chipping, the most important reason not being the bundling cost (Eliasson 2011b), but because it is difficult to efficiently plan the operations and thereby recover the bundling costs through cost reductions in extraction, transport and chipping.

While the structure of roundwood supply chains has largely remained unchanged since 2000, biomass energy supply chains have changed significantly in the past 20 years. These changes concern both the equipment used (Hakkila 2004, Thorsén et al. 2011, Palmér et al. 2016) and improved planning and supply chain management (Windisch 2015, Iwarsson Wide 2016, Väätäinen 2018, Prinz 2019).

\subsection{Truck Transport and Roads}

In the early years of this century, it was suggested that increased payloads, achieved either through low- er tare weights or increased GVW, would increase fuel economy and reduce transport costs and $\mathrm{CO}_{2}$ emissions (Löfroth and Nordén 2003). Other potential positive effects on road wear, road safety and number of drivers needed prompted the idea to increase the capacity of truck combinations. Fifteen professionals representing transport contractors, wood-buying companies, forest and energy industries, and other experts stated that the biggest problems facing the logistics of industrial roundwood and wood for energy production were fuel prices, problems with the recruitment of drivers and the conditions of the road network (Väätäinen et al. 2014).

At a time when the legal limit for GVW was $60 \mathrm{t}$, Väkevä et al. (2000) and Nurminen and Heinonen (2007) studied costs, time and carried out follow-up studies of timber trucks. Väkevä et al. (2000) examined the time and cost aspects of timber collection and truck transport when loads were single-sourced (i.e. from one landing) compared with multi-sourced (from multiple landings to fill the load). The costs were $2.8 \%$ higher when $50 \%$ of all loads were multi-sourced loads than if all were single-sourced (Väkevä et al. 2000). Nurminen and Heinonen (2007) found that, in single-source loading, for $19 \%$ of the time the trucks were driven empty, $21 \%$ of time was spent on log deck activities, $33 \%$ on driving loaded, $16 \%$ on unloading, and $10 \%$ on repairs, breakdowns and other driving. Corresponding figures for multi-sourced loading where 16\%, 22\%, 26\%, 15\% and $10 \%$, with an additional $11 \%$ spent on driving between decks.

Sweden started the first trials with larger trucks. Both $25.25 \mathrm{~m}$ trucks with $74 \mathrm{t}$ GVW and a $30 \mathrm{~m}$ truck with $90 \mathrm{t}$ GVW were tested on selected roads (Löfroth and Svensson 2012). These larger vehicle combinations were shown to reduce fuel consumption and transport costs by $7 \%$ to $20 \%$ compared to the then standard $60 \mathrm{t}$ vehicles (Fogdestam and Löfroth 2015). These results led the industry to start exerting pressure on politicians and road authorities to revise the maximum GVW on public roads. In Finland, seven HCT combinations transporting roundwood and five transporting chips have been in operation (Venäläinen and Poikela 2019).

In two follow-up studies of a wood procurement company, the reduction in fuel consumption of $6.2-12.5 \%$ was observed soon after GVWs and dimensions were changed by law in 2013 (Palander 2016, 2017). However, Palander (2017) stated that the reduction in fuel consumption would be even greater after the sector had fully adopted the higher limits. According to Venäläinen and Poikela (2019), fuel consumption and transport costs from roadside landing to mill could be reduced by $10 \%$ by using an $84 \mathrm{t}$ combination rather 
than a $76 \mathrm{t}$ combination. In transportation starting from a terminal with 84 and $104 \mathrm{t}$ combinations, the possible cost savings have been estimated to as much as $20 \%$ (Venäläinen and Poikela 2019). Sauna-aho et al. (2018) simulated fuel consumption for a standard $76 \mathrm{t}$ combination and a $100 \mathrm{t} \mathrm{HCT}$ combination. They found that the HCT combination could reduce fuel consumption and $\mathrm{CO}_{2}$ emissions by $14-16 \%$ compared to the standard combination. Svenson and Fjeld (2016) applied a regression model when investigating the impact of road geometry and surface roughness on the fuel consumption of conventional $60 \mathrm{t}$ trucks using the vehicles' CAN-bus data. Their study showed an average fuel consumption of 71.4 litres per 100 kilometres.

In Finland the impact of increased GVWs on load capacity and axle weights in practice was evaluated in 2013-2014 by Näsärö and Korpilahti (2015). They noted the difficulty of attaining maximum GVW with fouraxle trucks without a loader and when transporting light pulpwood in summertime. A similar result was obtained by Palander and Kärhä (2017), who reported the difficulty of attaining full GVW when transporting $3.5 \mathrm{~m}$ and $4 \mathrm{~m}$ pulpwood without a loader.

Heinonen (2017) compared three HCT combination vehicles (length 31-34.5 m, GVW 90-104 t) with reference vehicles of standard size (length $25.25 \mathrm{~m}$, GVW 64-76 t). Although it took longer to overtake HCT trucks, and queues behind HCT trucks were longer compared to reference trucks, the differences in overtaking safety were minor. The mobility of the tested HCT combinations in terms of slipping, stability and braking is good enough for normal traffic conditions (Pirnes et al. 2018). It has been estimated that wider introduction of $84 \mathrm{t}$ combinations for roundwood transport could reduce the total number of kilometres driven by about $5 \%$, but could result in some transports being shifted from rail to roads (Lapp and likkanen 2017).

According to Laitila et al. (2016a) and Prinz et al. (2019), large chip truck alternatives, such as the $69 \mathrm{t}$ truck-trailer unit or the $76 \mathrm{t}$ truck-trailer option, are mainly used for transporting forest industry by-products or forest chips from terminals to heat and power plants in Finland. In the study, the $69 \mathrm{t}$ truck-trailer proved its feasibility when the bulk weight of transported material did not limit the payload (e.g. industry by-products or dry forest chips with low bulk weight density). With denser forest industry by-products, such as sawmill wood chips and bark, the $76 \mathrm{t}$ truck-trailer was more feasible (Laitila et al. 2016a). Prinz et al. (2019) studied forest chips transport from roadside landings to a plant. The modern $69 \mathrm{t}$ truck-trailer equipped with electronic trailer steering system increased annual deliveries to the plant by approximately $10 \%$ and with a lower transport cost than a $60 \mathrm{t}$ chip truck. According to Laitila et al. (2016a) and Prinz. et al. (2019), the higher moisture content of chips, and thereby larger bulk weight, increased transport costs by lowering the energy density of biomass and, ultimately, prohibited full utilisation of the loading capacity of the truck-trailers in terms of load volume.

In a global perspective, the road density in Finland is very high. The average forwarding distance varies from $300-400 \mathrm{~m}$ in southern Finland to roughly $1000 \mathrm{~m}$ in parts of northern Finland (Uotila and Viitala 2000). Unfortunately, maintenance of both public and private roads has suffered from lack of funding, and approximately $9 \%$ of total transports are on roads that are in poor condition (https://www.liikennefakta.fi/turvallisuus/tieliikenne/tieverkon_kunto). Any extra funding should be earmarked for improving the current road network rather than extending it. Poor condition of roads and lack of winter maintenance were also seen as problems by truck contractors (Malinen et al. 2014, Väätäinen et al. 2014). A number of bridges already restrict GWV because they cannot support the current maximum weight. At the same time, the GWV of trucks has increased, accentuating the importance of up-todate and comprehensive road information to improve planning of road maintenance and transports. For this reason, a service platform of private road information is currently being planned (Venäläinen et al. 2019). The platform would combine data from existing sources (such as the national road and street database and data from forest companies) with advanced data collection methods (e.g. remote sensing and CAN bus data).

Road wear in all road classes and rutting of road surfaces, especially on gravel roads, is unavoidable when driving with heavy weights, particularly on poor-quality roads and during wet seasons. After the change in legislation for transports, new truck concepts were expected to reduce stress on roads, because of lower axle weights and the obligation for twin tyres (Näsärö and Korpilahti 2015). A reduction of road wear of as much as $20 \%$ has been estimated if a $100 \mathrm{t} \mathrm{HCT}$ combination is used instead of a standard $76 \mathrm{t}$ combination on paved roads (Sauna-aho et al. 2018). However, the simulation study by Sauna-aho et al. (2018) showed that the advantage of the HCT combination in terms of road wear is dependent on the load weight. Road wear caused by the standard combination was lower than the one of the HCT combination when wood was very light, otherwise the HCT combination caused lower road wear.

Aimed at facilitating transports in poorer road conditions and reducing road maintenance costs, the Central Tyre Inflation (CTI) system has been tested and 
adopted to some extent in Finland and Sweden. In Finland, the state forest company Metsähallitus has started operating CTI trucks in its timber transports. The system has been shown to reduce rutting, and reduced tyre pressure also helped on steep slopes and soft roads (Siekkinen and Korpilahti 2015). However, the experiences of truck contractors were less positive, reporting only a minor increase in transported volumes and that CTI provided only little assistance in difficult conditions (Keränen and Malinen 2019). Above all, the contractors felt that the distribution of benefits and costs with CTI was unfair.

\subsection{Terminal Concepts and Terminal Logistics}

In the Nordic context of secured and efficent biomass logistics, the Nordic studies have identified several reasons to use terminals as a part of the supply chain. Terminals enable the supply system to cope with thaw conditions and seasons of poor road quality, and meet legislation requirements regarding the prevention of insect damage. Biomass supply via terminals secures the supply to end-use facilities at times when direct supply from roadside landings is minimal (Terminaalitoiminnot... 2017). Log yards or storage sites next to mills and power plants may sometimes be limited in size, so feed-in terminals may be required to ensure a constant feed of biomass to the processing or conversion facilities (Väätäinen et al. 2017). Terminals offer a better environment for controlling fuel properties of forest chips (moisture, mixing, particle size etc.) and volumes, and for comminuting forest biomass (Kons et al. 2014). Terminals can alleviate problems caused by the seasonality of fuel demand and variation in supply from roadside landings, and even weekly variations for the big biorefineries, by balancing the supply of biomass feed through the year (Venäläinen and Ovaskainen 2016, Väätäinen et al. 2017). Additional storage of roundwood at terminals may be essential after severe large-scale forest damage (e.g. storm damages). Various sizes of terminals are also used for timber exchange between forest industries and accumulation buffers for the low-volume assortments when transporting mixed assortment loads (Venäläinen and Ovaskainen 2016). Finally, terminals are typically used at nodes of multimodal supply chains, where transport mode (railway, waterway) or size of transport unit (trucks with bigger payloads) changes. Venäläinen et al. (2017b) described the purposes of terminal use and the location of these terminal types in the supply chain of roundwood and energy wood in more detail.

Various kinds of ownership structures and co-operatives operate terminals, but big end-use facilities (bio- refineries) largely rely on their own network of terminals. The closer the terminal is located to the end-use facility, the more often it is owned or co-owned by the user company (Enström et al. 2013). In Sweden, 10 million t of wood annually is transported through 50 loading terminals, according to transport data from 2016 and 2018 (Davidsson and Asmoarp 2019, Asmoarp et al. 2019). In Finland, the corresponding figures were 90 loading terminals and 8.2 million $\mathrm{t}$ in 2016 (Iikkanen and Lapp 2018). For large pulpmills and biorefineries, a carefully planned terminal network and transport logistics via terminals are essential in securing the supply of timber with high volumes.

Enström et al. (2013) and Kons et al. (2014) classified biomass terminals according to location, size and ownership. In a Finnish-Swedish perspective, three types of terminals for energy biomass were identified by Virkkunen et al. (2015), according to their purpose and location. A satellite terminal is located near fuel resources, away from usage sites. These terminals are often large and complex fuel-processing and storage sites, with the option of using rail or barge for secondary transport. The feed-in terminal is a second type, functioning as an extra storage facility close to the end user to balance fuel supply when storage space at the heat or power production facility is insufficient. The third type of fuel terminal is the upgrading terminal, where possible ways of upgrading fuel include artificial or natural drying (post- or pre-comminution), sieving, blending and densifying (post-comminution).

According to the forest energy terminal survey by Kons et al. (2014), 74\% of terminals were smaller than $2 \mathrm{ha}, 8 \%$ were bigger than $5 \mathrm{ha}$, and the rest were $2-5$ ha. For roundwood assortments, the small terminals (<2ha) handled approximately half of the volume flow. Venäläinen and Ovaskainen (2016) studied industrial roundwood, and estimated that up to 2300 small intermediate storage sites are used as short-term terminals next to truck routes to industries.

Terminal productivity and costs have been calculated for energy biomass (e.g. Rinne 2010, Brunberg 2014, Virkkunen et al. 2015, Virkkunen et al. 2016). Virkkunen et al. (2015) calculated that comminution accounted for roughly $2 / 3$ of the total terminal cost. According to Rinne (2010), stationary chippers were $50-60 \%$ more productive and roughly $17 \%$ more costefficient than mobile chippers for all biomass types. Results were $180 \mathrm{MWh} / \mathrm{E} 15$ for productivity and EUR 1.32/MWh for costs relating to the logging residues. Handling costs represented $10 \%$ of the total cost for forest fuel terminals. Karttunen et al. (2012b) found the figure of EUR 0.6-0.9/MWh for unloading, loading, piling and storage of chips, based on a Finnish case 
study. Enström (2009) found the cost of EUR 0.9/MWh for handling with a wheel loader at a feed-in terminal for chipped residues. The main cost drivers for material handling were density of the material, the size of the individual grapple load, and work rotation of the machine (Virkkunen et al. 2015).

Establishment costs for terminals vary greatly, according to circumstances such as the extent of ground work required, pavement, measurement facilities and investments in connecting roads or possibly rail connections. For the comminuted material, a paved surface is an advantage for improving fuel quality, but Kons et al. (2014) reported that $31 \%$ of forest fuel terminals had no paved area. Virkkunen et al. (2015) calculated that terminal establishment costs were approximately $5 \%$ of the total costs of forest fuel terminals, if comminution was included in costs. Enström (2009) found the higher cost of EUR 230,000/ha for the establishment of a terminal area. When the railway connection into the terminal was included, Frosch and Thorén (2010) reported that the total train operating costs between two terminals requiring diesel shunting and repositioning of the train, were more than $50 \%$ higher than operation between two electrified terminals with no need for shunting or repositioning. Efficient terminal handling also increases the number of weekly deliveries by train, which has a significant impact on the cost (Enström 2009, Frosch and Thorén 2010, Flodén 2016).

\subsection{Storage of Wood}

The storage of wood will always be an integral part of the forest biomass supply chain. Storage and drying of energy wood has been a common subject of research, and comprehensive knowledge has been generated. Most of the recent studies have focused on energy wood supply chains.

Supply of fresh wood to pulp, paper and sawmill industries is important, with the wood moisture content normally a good indicator of freshness. Depending on the season and local weather variations, as well as the storage properties, the harvested wood dries out at varying speeds. The logistical plans are based on assumptions about how fast the wood is drying, producing a maximum number of days of storage before the wood must be delivered to mills with retained quality (Wilhelmsson et al. 2011). A tool for calculating the rate at which timber dries under different weather, handling and storage conditions was developed by Wilhelmsson et al. (2005). Lindblad and Repola (2019) reported on the impact of storage time of pine and birch pulpwood on the fresh weight density of timber. Models for the energy wood supply chain, to calculate weather-related drying of the energy wood storages, have been developed by Routa et al. $(2015,2016)$ and Lindblad et al. (2018).

Storage conditions are critical in maintaining fuel quality. Forest chips are stored for an average of six months in Finland (Wihersaari 2005, Jämsén et al. 2015) and uncomminuted energy wood is stored for typically $8-10$ months (Routa et al. 2018). Stumps are often stored for 1-2 years before comminution. Moisture management is a key element for improving net calorific value and cost-efficiency of energy wood supply, throughout the supply chain. The choice of storage location and method is usually influenced by biological, economic and logistic considerations (Routa et al. 2018).

Nurmi and Hillebrand (2007) reported that moisture content in pine and birch stem wood can fall below $30 \%$ during the summer. Erber et al. (2014) showed that moisture content in small logs dropped from $50.1 \%$ to $32.2 \%$ when stored in Austria and from $62.2 \%$ to $38.6 \%$ when stored in Finland. Minimising the variation in moisture content and implementing procedures to control moisture content during storage are key factors in improving fuel quality and reducing losses (Routa et al. 2018). Covering biomass, both loose logging residues stored in windrows and comminuted material, has a clear advantage, since it simultaneously protects the biomass from rewetting and reduces dry matter losses during storage. The effect of cover and its profitability is related to local weather conditions and storage time (Nurmi and Hillebrand 2007). According to Röser et al. (2011), covering piles was beneficial for coniferous and deciduous logwood in the wet climates of Scotland and Finland. Anerud et al. (2018) reported the available energy in covered forest residue chips to be $5.3 \%$ higher than in uncovered piles after seven months of storage, but no differences were reported after the first three months.

Storing forest biomass outdoors can cause substantial dry matter losses, where degradation rates can vary depending on climatic conditions and weather regimes. Dry matter loss rates of $0.1-4 \%$ have been reported for small-diameter stem wood (Routa et al. 2018). For logging residues, average dry matter losses of $1-3 \%$ per month have been reported (e.g. Filbakk et al. 2011, Jirjis and Norden 2005, Nurmi 1999, Routa et al. 2015). For coniferous wood chips, monthly dry matter losses between 0.3 and $5.5 \%$ during storage have been reported (Anerud et al. 2018, Juntunen et al. 2013, Jylhä et al. 2017). The decomposition rate in whole-tree or forest residue chip piles has been found to be higher than in stemwood chip piles (Jylhä et al. 2017, Thörnqvist 1985). In bark storage, dry matter losses of up to $10 \%$ per month have been observed (Fredholm and 
Jirjis 1988, Anheller 2009). Initial moisture content can decrease dramatically during storage (Jirjis and Lehtikangas 1994, Lehtikangas and Jirjis 1998).

Laitila et al. (2017) calculated that, depending on transport distance (1-100 km), transport costs for chips made from fresh timber (55\%) and produced at roadside landings were EUR $0.26-1.62 / \mathrm{m}^{3}$ higher compared to chips made from stored timber with a moisture content of $40 \%$ with a $69 \mathrm{t}$ truck-trailer. Corresponding transport costs for fresh delimbed stems using a timber truck were EUR $0.19-0.71 / \mathrm{m}^{3}$ higher compared to transporting stored timber. Due to smaller payload, the transport costs of fresh timber rose more steeply compared to stored timber as a function of transport distance.

\subsection{Multimodal Transports}

\subsubsection{Railways}

Railway capacity and flexibility is limited by the number of available slots on the track, which are allocated by the Transport Administration agency. There are bottlenecks in railway capacity, which can be problematic, especially for companies that need more flexibility than that permitted by the annual application and planning process. These companies can only apply for remaining spot times (Enström 2009). Maximum permitted axle load and measurement regulations affect the efficiency of the system (Vierth 2014).

On most of the Swedish and Finnish railways, $22.5 \mathrm{t}$ is the most common limit for the axle load, but the systems are being upgraded, and most of the infrastructure today now permits $25 \mathrm{t}$ per axle (Swedish Transport Agency 2018). In Sweden a typical timber rail car with two axles (of the LNPS type) loads $33.5 \mathrm{t}$ (adapted for $22.5 \mathrm{t}$ axle load) and with four axles (of the LAAPS type) can load up to $73.9 \mathrm{t}$, if $25 \mathrm{t}$ of axle load is permitted (Vierth 2014, Green Cargo 2019). Finnish timber rail cars have four axles and can carry 57-65.5 t, depending on car type (VR Transpoint 2019). The four-axle chip rail cars have a capacity of $48.5 \mathrm{t}$.

In Sweden forestry companies have been looking for opportunities to reduce transport costs by using longer and heavier trains and improving the efficiency of electricity use (Vierth 2014). The study reports that freight trains longer than $630 \mathrm{~m}$ were possible, but this would require adaptions to the system and its operators, and would be expected to have negative effects on passenger traffic. In Finland, according to an assessment by Venäläinen (2019), keeping the gross timber train weight constant but increasing the height and width of load space would increase total train load space by $17-19 \%$. Keeping the train length constant, higher and wider load spaces would increase total train load space by $29-36 \%$. For the chip-transporting trains, the increases in total train load space were $18-20 \%$ and $40-48 \%$ respectively. The assessment did not consider all constraints set by the rail network (Venäläinen 2019).

Troche (2009) presented a model called EvaRail, which was based on a train system with several flows. A Swedish transport case between Mora and Gävle $(320 \mathrm{~km})$, with an annual flow of 225,000 tof raw timber, was evaluated using the model. The capital costs for the vehicles accounted for a third of the total cost. Other cost proportions were the driver (19\%), shunting $(9 \%)$, energy $(6 \%)$ and infrastructure fees $(4 \%)$. The study calculated a cost reduction potential of $5.3 \%$ if the maximum permitted axle load were increased from 22.5 to 25 t. Flodén (2016) presented a transport case study for forest fuel supply from the roadside landing by road and rail to a district heating plant. The supply cost in the base scenario with five deliveries per week (three from a $265 \mathrm{~km}$ distance, and two from a $471 \mathrm{~km}$ distance) was EUR 9.47/MWh, of which train transport accounted for EUR 3.33/MWh. The $\mathrm{CO}_{2}$ emissions from the entire system were calculated to be $2.92 \mathrm{~kg} / \mathrm{MWh}$, of which less than $10 \%$ derived from train transport. In the biomass supply case, electrified rail was used for the main transport but diesel shunting was also required.

The GIS analysis by Tahvanainen and Anttila (2011) showed that transport of forest chips by rail was the most cost-efficient supply chain when transport distance was over $145 \mathrm{~km}$. For whole trees and logging residues, the breakpoint was $160 \mathrm{~km}$. The total cost of transporting logging residue chips by train from forest landing to a plant was slightly over EUR $0.1 / \mathrm{m}^{3} \mathrm{~km}$ at a distance of $200 \mathrm{~km}$. As the comparison was with $60 \mathrm{t}$ trucks, the breakpoint distances would be higher with the current $76 \mathrm{t}$ trucks. In another GIS-based case study, Nivala et al. (2015) reported that train transport was more expensive than truck transport for delimbed stemwood with a $76 \mathrm{t}$ truck for the full range of transport distances (maximum $490 \mathrm{~km}$ ). A $68 \mathrm{t}$ truck chain was cheaper below $465 \mathrm{~km}$, while a $60 \mathrm{t}$ truck was more expensive even for the shortest train transport distance $(350 \mathrm{~km})$. The road connection was found to be much more direct than the rail connection. As with all case studies, the results are location- and case-specific.

\subsubsection{Waterways}

Recent studies of barge transport for forest biomass in Finland and Sweden have assessed its strengths and weaknesses (Sorsa 2013, Enström 2015, Juronen 2017, Karttunen et al. 2008, Airas 2018, Pentti 2018). Strengths 
included environment-friendly and energy-efficient transport, cost efficiency for longer distances, decent buffer sizes in loading harbours, and the possibility for supplementary transports during periods of high work load for truck and train transports. Identified weaknesses were that vessels can only operate on open waterways, uncertainties regarding the length of the transport season, unloading difficulties at harbours (e.g. capacity, scheduling, limited buffer areas), timing difficulties of barge transports (due to e.g. weather and work shifts at harbours) and shallow waterways with varying water depths on some routes.

Studies relating to waterway transport logistics since 2000 have predominantly focused on barge transports using the discrete-event simulation method (Asikainen 2001, Karttunen et al. 2008, Sorsa 2013). According to Asikainen (2001) and Sorsa (2013), both cost efficiency and transport volumes could be improved and waiting times at harbours considerably reduced if interchangeable-barge logistics were used instead of fixed-barge logistics. An alternative and competitive option was a self-propelled barge with a navigation speed $10-20 \%$ higher, which reduced journey time (Sorsa 2013). Karttunen et al. (2008) and Enström (2015) discovered that the mismatch in work shifts of sub-systems (i.e. harbour operations vs. barge transports) quickly escalated transport costs. According to e.g. Johnson and Styre (2015) and Karttunen et al. (2018), efficient loading and unloading methods are important if vessel and barge transports are to be operated in a productive and cost-efficient manner. Enström (2015) concluded that it would require relatively big vessel loads and annual volumes of approximately $600,000 \mathrm{~m}^{3}$ to justify the use of a dockside crane to handle wood chips.

\subsection{Supply Chain Logistics}

Some authors have presented reviews of forest chip supply chains, logistics, procurement methods and future challenges. Díaz-Yáñez et al. (2013) focused on Europe, Routa et al. (2013) on Sweden and Finland, and Laitila et al. (2010a) on Finland, all based on expert evaluation and/or literature review. Kärhä (2011) conducted a survey of the machinery operating in forest chips supply to energy plants in 2007 , and provided an estimate of future machinery requirements for forest chip production in Finland. Väätäinen et al. (2014) reported on a comparable study for both industrial roundwood and energy wood transports in Finland, collating information on challenges and solutions in developing supply chain logistics from experts in transports and logistics. Venäläinen et al. (2017a) carried out a detailed analysis of the impact of seasonal supply variation on procurement costs of roundwood and the ways to reduce the impact in Finland.

Various system analysis methods have been used to study roundwood and biomass supply chain logistics. Static modelling has often been used for various biomass types, system configurations and case environments, e.g. Asikainen et al. (2001), Jylhä et al. (2010), Petty and Kärhä (2011), and Laitila and Väätäinen (2012). Fewer corresponding analyses have been carried out for roundwood, but one example is Nurminen et al. (2009). GIS-based static calculation modelling has been used, e.g. Ranta (2002), Laitila et al. (2010b), Tahvanainen and Anttila (2011), Ranta et al. (2012), Korpinen et al. (2013), Nivala et al. (2015), Laitila et al. (2015), Laitila et al. (2016a, 2016b), Laitila et al. (2017) in area-specific GIS analysis of biomass availability and procurement costs, using the stand data, and transportation distance from the delivery point as explanatory factors.

Various authors have used simulation by discrete event simulation (DES) and/or agent-based simulation (ABS), e.g. Asikainen (2010), Karttunen et al. (2012b), Karttunen et al. (2013), Belbo and Talbot (2014), Eriksson (2014a, 2014b), Windisch et al. (2015), Eliasson et al. (2017), Eriksson et al. (2017), Väätäinen et al. (2017), Aalto et al. (2019), Prinz et al. (2019) and FernandezLacruz et al. (2020), to model biomass supply chains for energy, typically in case-specific studies in Nordic conditions. There have been fewer simulation studies for industrial roundwood. Asikainen (2001) and Sorsa (2013) focused on waterway transports of roundwood by barges and Annevelink et al. (2017), Korpinen et al. (2019) and Väätäinen et al. (2020) considered road transports of roundwood.

Simulation-based system analysis has been introduced to model the system operation in more detail and simulate events. The level of analysis has been more tactical and/or operational (i.e. monthly or weekly level) than strategic. In the supply of logging residue forest chips from landings to heat and power plants, for example, the costs of roadside chipping and truck transport are roughly equal at an average transport distance of 60-70km (e.g. Eliasson et al. 2017, Laitila et al. 2016a, Windisch et al. 2015, Väätäinen et al. 2017). In forest chip supply, based on comminution at landings, both transport and chipping costs increase with transport distance (Eriksson et al. 2014a, Väätäinen et al. 2017, Prinz et al. 2018). Chipping costs increase with distance because of increased waiting time at the landings, reducing productivity. However, waiting for the chipper or the chip trucks always occurs in such a hot chain, regardless of transport distance. In studies by Eriksson et al. (2014b) and Prinz et al. (2019), the cost of forest chip supply (i.e. chipping and trucking) 
increased by nearly EUR 4/MWh when transport distance from landing to plant increased from $20 \mathrm{~km}$ to $100 \mathrm{~km}$. Eriksson et al. (2014b) evaluated the impact of system factors (handling, fuel quality, machine efficiency and site characteristics) on the stump fuel cost from the site to fuel delivery point.

Supply chain analysis concerning the effects of incorporating the terminal into the supply chain has been performed by Väätäinen et al. (2017) and FernandezLacruz et al. (2020) by DES method. For scenarios using terminals as part of the forest chips supply to end-use facility the supply costs for the combined scenarios were 1.4-3.1\% higher in Väätäinen et al. (2017) and $5-11 \%$ higher in Fernandez-Lacruz et al. (2020), compared to direct supply. Despite the increase in supply costs, it may be convenient to use a terminal to allow for more balanced working opportunities thoroughout the year and securing the demand of chips during peak times. Also cost compensation can be gained through the higher annual use of a fuel supply fleet (Väätäinen et al. 2017, Fernandez-Lacruz et al. 2020).

Optimisation methods have been used in the analysis of roundwood supply, e.g. Rönnqvist (2003), Carlsson and Rönnqvist (2005), Forsberg et al. (2005), Skjäl et al. (2009) and likkanen et al. (2010). Optimisation has been used in the analysis of forest fuel supply, e.g. Gunnarsson et al. (2004), Flisberg et al. (2012), Palander (2015) and Palander et al. (2018). Palander and Voutilainen (2013) added terminals into the supply chain. LCA and GHG emission analyses have been applied to biomass supply chains, e.g. Berg and Lindholm (2005), Kariniemi et al. (2009), Lindholm et al. (2010), Jäppinen et al. (2014), de la Fuente et al. (2017), and Raghu et al. (2020).

In the system analysis of roundwood and biomass supply, optimisation methods (e.g. linear programming, LP, and mixed integer programming, MIP) have produced results and decision support at predominantly strategic and tactical levels (yearly or monthly level). Forsberg et al. (2005) and Iikkanen et al. (2010) presented a decision support system for strategic and tactical transportation planning in roundwood supply from the harvesting areas to delivery points. Such nationwide optimisation tools support strategic decision making with regard to, e.g. terminal location and capacity, proportions of transport modes, proportions of domestic and imported wood, and use of train systems. In tactical planning, the tools could be used for aspects such as the destinations of roundwood supply and potential back-haul routes (Forsberg et al. 2005, likkanen et al. 2010).

Some studies have examined cost efficiency of various transport modes with regard to supply costs. Roundwood floating becomes more cost efficient after
$130 \mathrm{~km}$ (Iikkanen et al. 2010), barge transport of forest chips by waterways after $150 \mathrm{~km}$ (Karttunen et al. $2012 b$ ), train transport of roundwood after $145 \mathrm{~km}$ (Iikkanen et al. 2010), and train transport of forest chips after $135 \mathrm{~km}$ (Tahvanainen and Anttila 2011). These figures are when transport costs are compared to direct truck transport by $60 \mathrm{t}$ trucks from landing to delivery point. Pre-trucking to loading terminals was included in the multimodal transport systems. However, it must be remembered that these studies were carried out when GVW was limited to $60 \mathrm{t}$. Current transports with bigger trucks will increase the breakpoint distances Laitila et al. (2016a), Venäläinen and Poikela (2019) and Väätäinen et al. (2020) calculated distances in relation to different GVWs.

Venäläinen et al. (2017a) estimated that the seasonality of wood procurement adds approximately EUR 70 million to the procurement costs of roundwood. The variation in monthly harvest volumes and transports from landings is caused by poorer bearing conditions in some forest and gravel roads, generating additional costs for harvesting, timber storage (due to timber degradation and tied capital) and road maintenance. Venäläinen et al. (2017a) calculated that these factors represented $59 \%, 13 \%$ and $10 \%$ respectively of the additional procurement costs.

\section{Discussion}

The review of roundwood and biomass logistics in Finland and Sweden produced an extensive list of relevant studies. This was the first review relating to the supply logistics in these countries. At operative and business scales, the level of technological advancement, history, entrepreneurial culture, infrastructure and climate conditions are similar in the two countries. This review excluded studies relating to entrepreneurial and business studies, and logistics IT systems, which are important in planning, managing and operating transports and supply logistics. The exclusion of studies solely related to harvesting (cutting and forwarding), operations at roadside landing (e.g. chipping, baling), and log yard logistics without the connection to other logistic operations further reduced the number of studies in the review. The list of articles is not comprehensive, partly due to the numerous Master's theses from universities with forestry educational programmes and smaller project reports in Finland and Sweden.

The Nordic countries have been the forerunners in developing and piloting, as well as exporting the CTL technology. Roundwood harvested and transported using CTL technology is supplied to processing industries on a large scale in Central Europe, North-West 
Russia, Eastern Canada, South America, South Africa and some parts of East Asia. CTL cutting and timber supply comprises approximately $50 \%$ of the total industrial cuttings in the world. To introduce an international perspective to this review, the findings from Nordic studies are interpreted in relation to studies carried out in other countries, to some extent.

Most studies published since 2000 have concentrated on supply logistics of forest biomass for heat and power. This has also been observed in earlier reviews of roundwood and forest biomass logistics by Koirala et al. (2018) and Acuna et al. (2019). Several other review studies have focused solely on forest energy procurement and supply (Routa et al. 2013, Wolfsmayr and Rauch 2014, Ghaffariyan et al. 2017, Erber and Kühmaier 2017, Kogler and Rauch 2018, Kühmaier and Erber 2018, Malladi and Sowlati 2018 and Spinelli et al. 2019). In the Nordic perspective, more studies have examined new system configurations and supply logistics for biomass supply systems for heat and power than for industrial roundwood. This is because operations are less standardised, with hot supply systems and machine interactions (e.g. chipper has to wait for the chip truck or vice versa). This has led to the setting up of a large number of research programmes and projects on biomass supply in the late $20^{\text {th }}$ and early $21^{\text {st }}$ centuries (e.g. Hakkila 2004, Brunberg 2016). However, mostly due to increasing masses and dimensions of vehicles, distinct increment in publications related to roundwood logistics could be seen in recent years (see Fig. 2).

Based on publications found in the review, it can be concluded that roundwood and biomass supply chains and supply logistics are a complex systems environment, varying greatly in terms of:

$$
\begin{aligned}
& \Rightarrow \text { feedstock properties } \\
& \Rightarrow \text { transport infrastructure } \\
& \Rightarrow \text { handling and storage } \\
& \Rightarrow \text { impact of weather on the system } \\
& \Rightarrow \text { technologies used } \\
& \Rightarrow \text { performance of the supply fleet } \\
& \Rightarrow \text { number of wood assortments } \\
& \Rightarrow \text { properties of each assortment. }
\end{aligned}
$$

As an example, truck transport of timber is much more complex than the transport of refined forest products (e.g. standard-sized pulp bales). Many systems analysis studies have been conducted around the world using a variety of mathematical programming techniques, e.g. linear programming, mixed-integer programming, heuristics, simulation techniques and geographical information systems (see e.g. Shen and Sessions 1989, Kanzian et al. 2009, Rauch and Gronalt
2011, Acuna et al. 2012, Zamora et al. 2013, Acuna and Sessions 2014, Zamora-Cristales and Sessions 2016, Kühle et al. 2019). Acuna et al. (2019) argue that these research methods are essential to provide decision support for planning and managing the forest biomass supply at strategic and tactical levels. The number of forest biomass supply chain studies using systems analysis methods involving mathematical techniques has risen, mostly due to increasing experience and availability of such methods, as well as improved computation capacity and user-friendliness (e.g. Kogler and Rauch 2018, Acuna et al. 2019).

As is the case in this review, international studies have focused particularly on cost efficiency and performance of forest biomass transport by trucks (e.g. Acuna et al. 2012, Rauch and Gronalt 2011, Spinelli et al. 2009), fuel consumption (e.g. Klvac et al. 2013, Ghaffariyan et al. 2017) and payloads (e.g. Ian et al. 2004, Brown and Ghaffariyan 2016, Trzcinski et al. 2013, Hamsley et al. 2007). GVW and payloads have a direct impact on fuel consumption per driven distance, but when the calculation is switched to fuel consumption per driven kilometer, the influence is inverted. Thereby, reducing fuel consumption and GHG emissions for truck transports requires larger and heavier vehicles with bigger payloads (Palander and Kärhä 2017, Asmoarp et al. 2018, Venäläinen and Poikela 2019). Changes in legislation regarding maximum GVW allowed and insufficient experience of vehicles with several options for GVW and payloads justifies the large number of studies examining the impact of GVW on transport efficiency in Sweden and Finland. Trucks with high GVW have advantages in terms of load capacities, but long and heavy trucks are less flexible on small, narrow forest roads with limited turning areas at landings (Laitila et al. 2016a). They may also be limited by the bearing capacity of forest roads. Technical improvements to the manouverability of long trucks on forest roads include a liftable axle group or steering axles at the rear end of the trailer.

Properties of biomass change during storage, and the impact of this on the logistics chain is a significant theme in international research (Krigstin and Wetzel 2016, Eriksson et al. 2017, Routa et al. 2018). Models have been developed to predict changes in fuel quality, temperature changes in piles, and dry matter losses during large-scale storage (Erber et al. 2012, 2014, Raitila et al. 2015, Filbakk et al. 2011, Routa et al. 2015, 2016, Lindblad et al. 2018). The simultaneous development of storage guidelines and management models or tools will help to improve the utilisation of forest resources, reduce dry matter losses, reduce environmental impact, and reduce costs throughout the production chain. According to Kühmaier et al. (2016), the cost of transport- 
ing wood chips is reduced by EUR $0.32-0.49 / \mathrm{m}^{3}$ if the moisture content can be reduced from 55 to $35 \%$. Erber et al. (2016) showed that moisture content management increased truckload volume utilisation by $25 \%$ and transported calorific value by $48 \%$, and reduced the number of truck trips by over $20 \%$.

The forestry sector is facing several challenges regarding roundwood and biomass supply logistics. Climate change will increasingly impact harvesting at forest sites and transports on forest roads. This will result in even greater seasonality, severe abiotic and biotic damage to forests, and variation in timber supply. The use of terminals for wood storage will increase, thereby ensuring supply to end-use facilities. Forest utilisation and forest management regimes may change, carbon stock aspects must be considered, and exploitation methods and extraction volumes from forests may change in the future. We are already seeing that a key issue is training and recruitment of operators, as well as the problem of retaining operators on a more permanent basis in such a demanding work environment.

To conclude, logistics of roundwood and biomass supply comprise a considerable proportion of the procurement costs in biomass supply chain. Despite the complex operation environment and diversified supply logistics, efficiency can still be optimised in forest biomass supply logistics and overall system performance can be improved. Logistics and vehicle technology, as well as IT, DSS and automation system are constantly evolving, and more emphasis is now placed on environmental and social aspects. All these aspects drive and increase the demand for research and development in roundwood and biomass logistics.

\section{Acknowledgements}

This study was financially supported by the Academy of Finland under the Climate-Neutral and Resource-Scarce Finland -Strategic Research Programme in 2015-2020 (Project FORBIO, No. 14970) FORBIO (3500010200), the Swedish Energy Agency (Project 46959-1), and the Swedish Knowledge Foundationfunded PhD school FORIC+ at Mid-Sweden University. Special thanks goes to Mr. Leslie Walke for improving our English. We would like to acknowledge the CROJFE Editors-in-Chief for the invitation to prepare a review article on the given subject.

\section{References}

Aalto, M., Raghu, K.C., Korpinen, O.-J., Karttunen, K., Ranta, T., 2019: Modeling of Biomass Supply System by Combining Computational Methods - A Review Article. Applied Energy 243: 145-154. https://doi.org/10.1016/j.apenergy.2019.03.201
Acuna, M., Mirowski, L., Ghaffariyan, M.R., Brown, M., 2012: Optimising Transport Efficiency and Costs in Australian Wood Chipping Operations. Biomass and Bioenergy 46: 291300. https://doi.org/10.1016/j.biombioe.2012.08.014

Acuna, M., 2017: Timber and Biomass Transport Optimization: A Review of Planning Issues, Solution Techniques and Decision Support Tools. Croat. j. for. eng. 38(2): 279-290.

Acuna, M., Sessions, J., Zamora, R., Boston, K., Brown, M., Ghaffariyan, M.R., 2019: Methods to Manage and Optimize Forest Biomass Supply Chains: A Review. Current Forestry Reports 5(3): 124-141. https://doi.org/10.1007/s40725-01900093-4

Airas, A., 2018: Puutavaran vesitiekuljetus ja sen tulevaisuus Suomessa. [Waterway transport of roundwood and its future in Finland.] Master's thesis, University of Helsinki. In Finnish

Anerud, E., Jirjis, R., Larsson, G., Eliasson, L., 2018: Fuel Quality of Stored Wood Chips - Influence of Semi-Permeable Covering. Applied Energy 231: 628-634. https://doi.org/10.1016/j. apenergy.2018.09.157

Anheller, M., 2009: Biomass Losses during Short-term Storage of Bark and Recovered Wood. Master's thesis, dept of Energy and Technology, SLU, Uppsala.

Anttila, P., Korpilahti, A., Väätäinen, K., 2012: Puutavaran maantiekuljetusten kehittämispyrkimyksiä Suomessa ja Ruotsissa. [Development of road transports of timber in Finland and Sweden.] Metsätieteen aikakauskirja 2012/3: 179-186. In Finnish

Asikainen, A., 1995: Discrete-Event Simulation of Mechanized Wood-Harvesting Systems. Research Notes 38. 86 p.

Asikainen, A., 2001: Simulation of Logging and Barge Transport of Wood from Forests on Islands. International Journal of Forest Engineering 12(2): 43-50. https://doi.org/10.1080/14 942119.2001.10702445

Asikainen, A., Ranta, T., Laitila, J., Hämäläinen, J., 2001: Hakkuutähdehakkeen kustannustekijät ja suurimittakaavainen hankinta. [Cost Factors and Large Scale Procurement of Logging Residue Chips.] Research notes 131. 108 p. in Finnish

Asikainen, A., 2010: Simulation of Stump Crushing and Truck Transport of Chips. Scandinavian Journal of Forest Research 25(3): 245-250. https://doi.org/10.1080/02827581.2010.488656

Asmoarp, V., Enström, J., Bergqvist, M., von Hofsten, H., 2018: Improving Transport Efficiency - Final Report of the ETT 2014-2016 Project. Skogforsk, arbetsrapport 962-2018, 65 p.

Asmoarp, V., Davidsson, A., Gustavsson, O., 2020: Forestry Road Transports 2018 - The Current Situation Regarding the Flow of Biomass from Forest to Industry. Manuscript. Skogforsk report. In Swedish

Avain Suomen metsäteollisuuteen (A Key to Finnish Forest Industry), 2006: Metsäteollisuus ry, 126 p. In Finnish

Belbo, H., Talbot, B., 2014: System Analysis of the Supply Chains for Whole Tree Chips. Forests 5: 2084-2105. https:// doi.org/10.3390/f5092084

Berg, S., Lindholm, E.-L., 2005: Energy Use and Environmental Impacts of Forest Operations in Sweden. Journal of Cleaner Production 13(1): 33-42. https://doi.org/10.1016/j. jclepro.2003.09.015 
Brunberg, T., 2014: Skogsbränslets metoder, sortiment och kostnader 2013. [Forest fuels - methods, assortments and costs 2013]. Webresultat Nr. Nr 74-2014 Skogforsk, 2 sid. In Swedish

Brunberg, T., 2016: Forest Fuel - Trends over 5 Years. I: Palmér, C.-H., Eliasson, L., and Iwarsson Wide, M., Forest Energy for a Sustainable Future. Composite report from the R\&D programme efficient forest fuel supply systems 20112015. Skogforsk., Uppsala, Sweden sid: 36-37.

CSCMP, 2019: CSCMP Supply Chain Management Definitions and Glossary. Council of Supply Chain Management Professionals.

Carlsson, D., Rönnqvist, M., 2005: Supply Chain Management in Forestry - Case Studies at Södra Cell AB. Eur J Oper Res 163(3): 589-616. https://doi.org/10.1016/j.ejor.2004.02.001

Davidsson, A., Asmoarp, V., 2019: Forestry Road Transports 2016 - Current Situation Regarding the Flow of Biomass from Forest to Industry.

de la Fuente, T., Athanassiadis, D., González-García, S., Nordfjell, T., 2017: Cradle-to-Gate Life Cycle Assessment of Forest Supply Chains: Comparison of Canadian and Swedish Case Studies. Journal of Cleaner Production 143: 866-881. https:// doi.org/10.1016/j.jclepro.2016.12.034

Eliasson, L., 2011a: Chipper Trucks Increasingly Common. In the book Efficient Forest Fuel Supply Systems. Composite report from a four year R\&D programme 2007-2010; Thorsén, Å., Björheden, R., Eliasson, L., Eds.; Skogforsk., Uppsala, Sweden, 70-72.

Eliasson, L., 2011b: Follow-up of the John Deere Logging Residue Bundler. In the book Efficient Forest Fuel Supply Systems. Composite report from a four year R\&D programme 2007-2010; Thorsén, Å., Björheden, R., Eliasson, L., Eds.; Skogforsk., Uppsala, Sweden; 38-39.

Eliasson, L., 2016: Fuel production - Resource Efficient Comminution. In the book Forest Energy for a Sustainable Future. Composite report from the R\&D programme Efficient Forest Fuel Supply Systems 2011-2015; Palmér, C.-H., Eliasson, L., Iwarsson Wide, M., Eds.; Skogforsk., Uppsala, Sweden, 84-86.

Eliasson, L., von Hofsten, H., Johansson, F., 2016: Preventing Chipper Truck Breakdown. In the book Forest Energy for a Sustainable Future. Composite report from the R\&D programme Efficient Forest Fuel Supply Systems 2011-2015; Palmér, C.-H., Eliasson, L., Iwarsson Wide, M., Eds.; Skogforsk., Uppsala, Sweden, 96-97.

Eliasson, L., Eriksson, A., Motashami, S., 2017: Analysis of the Factors Affecting Productivity and Costs for a High-Performance Chip Supply System. Applied Energy 185 (part 1): 497-505. https://doi.org/10.1016/j.apenergy.2016.10.136

Enström, J., 2009: Railway Terminals Boost Efficiency of Energy-Wood Haulage. Resultat nr. 13:2009. Skogforsk. In Swedish

Enström, J., 2015: Possibilities for Coastal Maritime Transport of Forest Fuel in Sweden. Skogforsk report 874-2015. In Swedish with English summary
Enström, J., Athanassiadis, D., Öhman, M., Grönlund, Ö., 2013: Success Factors for Larger Energy Wood Terminals. Skogforsk report 813-2013. In Swedish with English summary

Enström, J., Winberg, P., 2009: Rail Transport of Forest Fuel. Arbetsrapport Nr. 678, Skogforsk, 27 p. In Swedish with English summary

Erber, G., Kanzian, C., Stampfer, K., 2012: Predicting Moisture Content in a Pine Logwood Pile for Energy Purposes. Silva Fennica 46(4): 555-567. https://doi.org/10.14214/sf.910

Erber, G., Kanzian, C., Stampfer, K., 2016: Modelling Natural Drying of European Beech (Fagus sylvatica L.) Logs for Energy Based on Meteorological Data. Scandinavian Journal of Forest Research 31(3): 294-301. https://doi.org/10.1080/02827581.201 5.1080294

Erber, G., Routa, J., Kolstrom, M., Kanzian, C., Sikanen, L., Stampfer, K., 2014: Comparing Two Different Approaches in Modeling Small Diameter Energy Wood Drying in Logwood Piles. Croat. j. for. eng. 35(1): 15-22.

Erber, G., Kühmaier, M., 2017: Research Trends in European Forest Fuel Supply Chains: a Review of the Last Ten Years (2007-2017) - Part One: Harvesting and Storage. Croat. j. for. eng. 38(2): 269-278.

Eriksson, G., Bergström, D., Nordfjell, T., 2013: The State of the Art in Woody Biomass Comminution and Sorting in Northern Europe. International Journal of Forest Engineering 24(3): 194-215. https://doi.org/10.1080/14942119.2013.852391

Eriksson, A., Eliasson, L., Jirjis, R., 2014a: Simulation-Based Evaluation of Supply Chains for Stump Fuel. International Journal of Forest Engineering 25(1): 23-36. https://doi.org/10. 1080/14942119.2014.892293

Eriksson, A., Eliasson, L., Hansson, P-A., Jirjis, R., 2014b: Effects of Supply Chain Strategy on Stump Fuel Cost: A Simulation Approach. International Journal of Forest Research 2014: Article ID 984395. https://doi.org/10.1155/2014/984395

Eriksson, A., 2016: Improving the Efficiency of Forest Fuel Supply Chains. Doctoral Thesis, No. 2016: 101. Swedish University of Agricultural Sciences, 73 p.

Eriksson, A., Eliasson, L., Sikanen, L., Hansson, P-A., Jirjis, R., 2017: Evaluation of Delivery Strategies for a Model for Weather-driven Analysis of Forest Fuel Systems (WAFFS). Applied Energy 188: 420-430. https://doi.org/10.1016/j.apenergy.2016.12.018

Fernandez-Lacruz, R., Eriksson, A., Bergström, D., 2020: Simulation-Based Cost Analysis of Industrial Supply of Chips from Logging Residues and Small-Diameter Trees. Forests 11(1): 21 p. https://doi.org/10.3390/f11010001

Filbakk, T., Hoibo, O., Dibdiakova, J., Nurmi, J., 2011: Modelling Moisture Content and Dry Matter Loss During Storage of Logging Residues for Energy. Scandinavian Journal of Forest Research 26(3): 267-277. https://doi.org/10.1080/02827581. 2011.553199

Flisberg, P., Frisk, M., Rönnqvist, M., 2012: FuelOpt: A Decision Support System for Forest Fuel Logistics. J Oper Res Soc 63: 1600-1612. https://doi.org/10.1057/jors.2011.157 
Flodén, J., 2016: Opportunities and Challenges for Rail Transport of Solid Wood Biofuel. EJTIR 16(4): 512-553. https://doi. org/10.18757/ejtir.2016.16.4.3157

Forests and Forestry in Sweden, 2015: The Royal Swedish Academy of Agriculture and Forestry, $24 \mathrm{p}$.

Forsberg, J., Romuk-Wodoracki, K., 2015: Time Studies and Analyses of the Internal Transport of Roundwood and Sawn Products at a Sawmill - A case study at Rörvik Timber Tvärskog AB. Bachelor thesis, Swedish University of Agricultural Sciences.

Fredholm, R., Jirjis, R., 1988: Seasonal Storage of Bark from Wet Stored Logs. Department of Forest Products, SLU. Uppsala In Swedish with English summary

Frosch, M., Thoren, P., 2010: Rail Transportation of Biofuels. Värmeforsk rapport SYS 08-835

Gadd, H., Werner, S., 2013: Daily Heat Load Variations in Swedish District Heating Systems. Applied Energy 106: 47-55. https://doi.org/10.1016/j.apenergy.2013.01.030

Ghaffariyan, M.R., Brown, M., Acuna, M., Sessions, J., Gallagher, T., Kühmaier, T., Spinelli, R., Visser, R., Devlin, G., Eliasson, L., Laitila, J., Laina, L., Iwarsson Wide, M., Egnell, G., 2017: An international review of the most productive and cost effective forest biomass recovery technologies and supply chains. Renew. Sust. Energ. Rev. 74: 145-158, https://doi. org/10.1016/j.rser.2017.02.014

Golser, M., Pichler, W., Hader, F., 2005: Energieholztrocknung. Holzforschung, Wien, Österreich.

Green Cargo, 2019: Goods wagon handbook.

Gunnarsson, H., Rönnqvist, M., Lundgren, J.T., 2004: Supply Chain Modelling of Forest Fuel. European Journal of Operational Research 158(1): 103-123. https://doi.org/10.1016/S03772217(03)00354-0

Hakkila, P., 2004: Developing Technology for Large-Scale Production of Forest Chips. Wood Energy Technology Programme 1999-2003. Technology Programme Report 6/2004. National Technology Agency, 98 p.

Heinonen, T., 2017: High Capacity Transport - ajoneuvoyhdistelmien vaikutukset liikennevirtaan. [The Effect of High Capacity Transport Vehicles on the Traffic Flow]. Research reports of the Finnish Transport Agency 48/2017, 237 p. In Finnish with English summary

Ihalainen, A., Vaahtera, E., 2018: Metsävarat - Forest resources. In Book Suomen metsätilastot - Finnish forest statistics; Vaahtera, E., Aarne, M., Ihalainen, A., Mäki-Simola, E., Peltola, A., Torvelainen, J., Uotila, E., Ylitalo, E., Eds.; Luonnonvarakeskus, Helsinki: 15-32.

likkanen, P., Keskinen, S., Korpilahti, A., Räsänen, T., Sirkiä, A., 2010: Raakapuuvirtojen valtakunnallinen optimointimalli. [A National Optimisation Model for Raw Wood Streams.] Liikenneviraston tutkimuksia ja selvityksiä 29/2010, 38 p. In Finnish with English summary

Iikkanen, P., Lapp, T., 2018: Rataverkon raakapuun kuormauspaikkaverkon kehittäminen. [Development of the Railway Raw Wood Loading Point Network.] Liikennevirasto, liikenne ja maankäyttö -osasto. Helsinki 2018. Liikenneviras- ton tutkimuksia ja selvityksiä 11/2018. 33 p. In Finnish with English summary

Jämsén, M., Agar, D., Alakoski, E., Tampio, E., Wihersaari, M., 2015: Measurement Methodology for Greenhouse Gas Emissions from Storage of Forest Chips - A Review. Renewable and Sustainable Energy Reviews 51: 1617-1623. https://doi. org/10.1016/j.rser.2015.07.064

Jäppinen, E., Korpinen, O.-J., Laitila, J., Ranta, T., 2014: Greenhouse Gas Emissions of Forest Bioenergy Supply and Utilization in Finland. Renewable and Sustainable Energy Reviews 29: 369-382. https://doi.org/10.1016/j.rser.2013.08.101

Jirjis, R., 1995: Storage and Drying of Wood Fuel. Biomass and Bioenergy 9(1-5): 181-190. https://doi.org/10.1016/09619534(95)00090-9

Jirjis, R., Lehtikangas, P., 1994: Fuel Quality and Dry Matter Loss during Storage of Logging Residues in a Windrow. Rapport-Sveriges Lantbruksuniversitet, Institutionen foer Virkeslaera (Sweden).

Jirjis, R., Norden, B., 2005: Fuel Quality and Working Environment during Storage and Handling of Composite Residue Logs. Report 7, Department of bioenergy, SLU, Uppsala.

Johnson, H., Styhre, L., 2015: Increased Energy Efficiency in Short Sea Shipping through Decreased Time in Port. Transportation Research Part A: Policy and Practice 71: 167-178. https://doi.org/10.1016/j.tra.2014.11.008

Juntunen, R., Hirvonen, M., Paukkunen, S., 2013: LAAVAhanke. Raportti Fortumin polttoainekentän hakeaumakokeista 2013. [LAAVA-project. Chip pile test.] Karelia-ammattikorkeakoulu, biotalouden keskus, 22 p. In Finnish

Juronen, M., 2017: Liiketoimintamallien kehitysmahdollisuudet raakapuun vesikuljetusten toimialalla. [Business Model Improvement Possibilities in the Wood Barge Transportation Industry.] Master's thesis, Lappeenranta University of Technology, $128 \mathrm{p}$.

Jylhä, P., Dahl, O., Laitila, J., Kärhä, K., 2010: The Effect of Supply System on the Wood Paying Capability of a Kraft Pulp Mill Using Scots Pine Harvested from First Thinnings. Silva Fennica 44(4): 695-714. https://doi.org/10.14214/sf.454

Jylhä, P., Hytönen, J., Alm, J., 2017: CO Release and Dry Matter Loss of Scots Pine Forest Chips Stockpiled from Late Summer to Winter. Biomass and Bioenergy 104: 36-44. https://doi. org/10.1016/j.biombioe.2017.06.003

Jylhä, P., Jounela, P., Koistinen, M. Korpunen, H., 2019: Koneellinen hakkuu: Seurantatutkimus. [Mechanised CTL Cuttings in Finland: Follow-up study.] Luonnonvara ja biotalouden tutkimus 11/2019. Luonnonvarakeskus. Helsinki, 53 p. In Finnish

Kariniemi, A., Kärhä, K., Heikka, T., Niininen, M., 2009: Feedstock Supply Chain $\mathrm{CO}_{2}$-eq Emissions - A Case Study on Forest Biomass for 2nd Generation Liquid Traffic Fuel. Metsätehon katsaus 38: 4 p.

Karttunen, K., Jäppinen, E., Väätäinen, K., Ranta, T., 2008: Metsäpolttoaineiden vesitiekuljetus proomukalustolla. [Inland Waterway Transport of Forest Fuels.] Lappeenranta University of Technology, Mikkeli, 54 p. In Finnish with English summary 
Karttunen, K., Lättilä, L., Korpinen, O.-J., Ranta, T., 2013: CostEfficiency of Intermodal Container Supply Chain for Forest Chips. Silva Fennica 47(4): article id 1047. https://doi. org/10.14214/sf.1047

Karttunen, K., Föhr, J., Ranta, T., Palojärvi, K., Korpilahti, A., 2012a: Puupolttoaineiden ja polttoturpeen kuljetuskalusto 2010. [Transportation Vehicles for Wood Fuels and Peat in 2010.] Metsätehon tuloskalvosarja 2/2012, 17 p. In Finnish

Karttunen, K., Väätäinen, K., Asikainen, A., Ranta, T., 2012b: The Operational Efficiency of Waterway Transport of Forest Chips on Finland's Lake Saimaa. Silva Fennica 46(3): 395-413. https://doi.org/10.14214/sf.49

Raghu, K.C., Aalto, M., Korpinen, O.-J., Ranta, T., Proskurina, S., 2020: Lifecycle Assessment of Biomass Supply Chain with the Assistance of Agent-Based Modelling. Sustainability 12(5): 14 p. https://doi.org/10.3390/su12051964

Keränen, S., Malinen, J., 2019: User Experiences with the Central Tire Inflation System on Timber Trucks in Finland. European Transport $\backslash$ Trasporti Europei 72(6): 1-16.

Kogler, C., Rauch, P., 2018: Discrete Event Simulation of Multimodal and Unimodal Transportation in the Wood Supply Chain: A Literature Review. Silva Fennica 52(4): article id 9984. https://doi.org/10.14214/sf.9984

Kons, K., 2019: Management of Forest Biomass Terminals. Doctoral thesis, Swedish University of Agricultural Sciences.

Koirala, A., Kizha, A.R., De Hoop, C.F., Roth, B.E., Han, H.-S., Hiesl, P., Abbas, D., Gautam, S., Baral, S., Bick, S., Sahoo, K., 2018: Annotated Bibliography of the Global Literature on the Secondary Transportation of Raw and Comminuted Forest Products (2000-2015). Forests 9(7): 28 p. https://doi. org/10.3390/f9070415

Kons, K., Bergström, D., Eriksson, U., Athanassiadis, D., Nordfjell, T., 2014: Characteristics of Swedish Forest Biomass Terminals for Energy. International Journal of Forest Engineering 25(3): 238-246. https://doi.org/10.1080/14942119.2014.980494

Krigstin, S., Wetzel, S., 2016: A Review of Mechanisms Responsible for Changes to Stored Woody Biomass Fuels. Fuel 175: 75-86. https://doi.org/10.1016/j.fuel.2016.02.014

Kühmaier, M., Erber, G., Kanzian, C., Holzleitner, F., Stampfer, K., 2016: Comparison of Costs of Different Terminal Layouts for Fuel Wood Storage. Renewable Energy 87(1): 544-551. https://doi.org/10.1016/j.renene.2015.10.048

Kühmaier, M., Erber, G., 2018: Research Trends in European Forest Fuel Supply Chains: A Review of the Last Ten Years (2007-2016) - Part Two: Comminution, Transport \& Logistics \& Logistics. Croat. j. for. eng. 39(1): 139-152.

Kühle, S., Teischinger, A., Gronalt, M., 2019: Optimal Location of Laminated Beech Production Plants within the Solid Hardwood Supply Network in Austria. Silva Fennica 53(3): article id 10074. https://doi.org/10.14214/sf.10074

Kuitto, P.-J., Rajala, P.S., 1982: Kokopuiden välivarastohaketus ja metsähakkeen autokuljetus. [Landing chipping of whole trees and truck transport of chips.] Metsätehon tiedotus 372, 14 p. In Finnish

Kärhä, K., 2011: Industrial Supply Chains and Production Machinery of Forest Chips in Finland. Biomass and Bioenergy
35(8): 3404-3413. https://doi.org/10.1016/j.biombioe.2010.11.016

Kärhä, K., Vartiamäki, T., 2006: Productivity and Costs of Slash Bundling in Nordic Conditions. Biomass and Bioenergy 30(12): 1043-1052. https://doi.org/10.1016/j.biombioe.2005.12.020

Kärhä, K., Jylhä, P., Laitila, J., 2011: Integrated Procurement of Pulpwood and Energy Wood from Early Thinnings Using Whole-Tree Bundling. Biomass and Bioenergy 35(8): 33893396. https://doi.org/10.1016/j.biombioe.2010.08.068

Lag om virkesmätning, 2014: Wood Measurement Act (2014:1005). Government offices of Sweden.

Laitila, J., Kärhä, K., Jylhä, P., 2009: Time Consumption Models and Parameters for Off- and On-Road Transportation of Whole-Tree Bundles. Baltic Forestry 15(1): 105-114.

Laitila, J., Leinonen, A., Flyktman, M., Virkkunen, M., Asikainen, A., 2010a: Metsähakkeen hankinta- ja toimituslogistiikan haasteet ja kehittämistarpeet. [Challenges and Development Needs of Pocurement and Supply Logistics of Forest Chips.] Espoo 2010. VTT Tiedotteita - Research Notes 2564, 143 p. In Finnish

Laitila, J., Heikkilä, J., Anttila, P., 2010b: Harvesting Alternatives, Accumulation and Procurement Cost of Small-Diameter Thinning Wood for Fuel in Central-Finland. Silva Fennica 44(3): 465-480. https://doi.org/10.14214/sf.143

Laitila, J., Väätäinen, K., 2012: Truck Transportation and Chipping Productivity of Whole Trees and Delimbed Energy Wood in Finland. Croat. j. for. eng. 33(2): 199-210.

Laitila, J., Kilponen, M., Nuutinen, Y., 2013: Productivity and Cost-Efficiency of Bundling Logging Residues at Roadside Landing. Croat. j. for. eng. 34(2): 175-187.

Laitila, J., Ranta, T., Asikainen, A., Jäppinen, E., Korpinen, O.-J., 2015: The Cost Competitiveness of Conifer Stumps in the Procurement of Ffor fuel in Southern and Northern Finland. Silva Fennica 49(2): 23 p. https://doi.org/10.14214/sf.1280 Laitila, J., Asikainen, A., Ranta, T., 2016a: Cost Analysis of Transporting Forest Chips and Forest Industry By-Products with Large Truck-Trailers in Finland. Biomass and Bioenergy 90: 252-261. https://doi.org/10.1016/j.biombioe.2016.04.011

Laitila, J., Lehtonen, E., Ranta, T., Anttila, P., Rasi, S., Asikainen, A., 2016b: Procurement Costs of Cereal Straw and Forest Chips for Biorefining in South-East Finland. Silva Fennica 50(5): 21 p. https://doi.org/10.14214/sf.1689

Laitila, J., Ahtikoski, A., Repola, J., Routa, J., 2017: Pre-Feasibility Study of Supply Systems Based on Artificial Drying of Delimbed Stem Forest Chips. Silva Fennica 51(4): 18 p. https:// doi.org/10.14214/sf.5659

Laki puutavaran mittauksesta, 2013: 414/2013. [Forest Products Measurement Law] Suomen säädöskokoelma. In Finnish

Lapp, T., Iikkanen, P., 2017: HCT-ajoneuvojen liikennejärjestelmävaikutukset. [Transport System Impacts of HCT Vehicles.] Liikenneviraston tutkimuksia ja selvityksiä 57/2017, 37 p. In Finnish with English summary

Lehtikangas, P., Jirjis, R., 1998: Storage of Wood Chips and Bark in Northern Sweden. Uppsala, Sweden, 30 p. 
Liikennefakta, 2019: Tieverkon kunto. [Road Network Condition.] Internet site. Accessed 16 Dec 2019. In Finnish

Lindblad, J., Routa, J., Ruotsalainen, J., Kolström, M., Isokangas, A., Sikanen, L., 2018: Weather Based Moisture Content Modelling of Harvesting Residues in the Stand. Silva Fennica 52(2): 16 p. https://doi.org/10.14214/sf.7830

Lindblad, J., Repola, J., 2019: Mänty- ja koivukuitupuun tuoretiheys paino-otantamittauksessa ja tuoretiheyden mallinnus varastointiajan perusteella. [Fresh Weight Densities and its Modeling by Storage Time of Pine and Birch by Using Weight Sampling Measurement.] Metsätieteen aikakauskirja 201910101. Tutkimusartikkeli. 26 p. In Finnish

Lindroos, O., Matisons, M., Johansson, P., Nordfjell, T., 2010: Productivity of a Prototype Truck-Mounted Logging Residue Bundler and a Road-Side Bundling System. Silva Fennica 44(3): 547-559. https://doi.org/10.14214/sf.148

Liss, J.E., 2006: Studier på nytt fordon för transport av skogsflis. [Studies fn a New Type of Chip Truck] Arbetsdokument Nr. 2 Högskolan Dalarna, inst f. matematik, naturvetenskap och teknik, Garpenberg, 28 p. In Swedish

Metsäteho, 2019: Puutavaran ja hakkeen HCT-yhdistelmien tutkimus. [Studies fn Transport of Round Wood and Chips by HCT Trucks.] Internet site. Accessed 16 Dec 2019. In Finnish

Metsätilastollinen vuosikirja 2014 (Finnish Statistical Yearbook of Forestry 2014), 2014: Official Statistics of Finland. Metsäntutkimuslaitos, 428 p. In Finnish

Nivala, M., Anttila, P., Laitila, J., 2015: A GIS-Based Comparison of Long-Distance Supply of Energy Wood for Future Needs from Young Forests to the Coast of Finland. International Journal of Forest Engineering 26(3): 185-202. https://doi. org/10.1080/14942119.2015.1108625

Nurmi, J., 1999: The storage of logging residue for fuel. Biomass and Bioenergy 17(1): 41-47. https://doi.org/10.1016/ S0961-9534(99)00023-9

Nurmi, J., Hillebrand, K., 2007: The Characteristics of WholeTree Fuel Stocks from Silvicultural Cleanings and Thinnings. Biomass and Bioenergy 31(6): 381-392. https://doi. org/10.1016/j.biombioe.2007.01.010

Nurminen, T., Heinonen, J., 2007: Characteristics and Time Consumption of Timber Trucking in Finland. Silva Fennica 41(3): 471-487. https://doi.org/10.14214/sf.284

Nurminen, T., Korpunen, H., Uusitalo, J., 2009: Applying the Activity-Based Costing to Cut-to-Length Timber Harvesting and Trucking. Silva Fennica 43(5): 847-870. https://doi. org/10.14214/sf.177

Nuutinen, Y., Björheden, R., 2016: Productivity and Work Processes of Small-Tree Bundler Fixteri FX15a in Energy Wood Harvesting from Early Pine Dominated Thinnings. International Journal of Forest Engineering 27(1): 29-42. https:// doi.org/10.1080/14942119.2015.1109175

Nuutinen, Y., Petty, A., Bergström, D., Rytkönen, M., Di Fulvio, F., Tiihonen, I., Lauren, A., Dahlin, B., 2016: Quality and Productivity in Comminution of Small-Diameter Tree Bundles. International Journal of Forest Engineering 27(3): 179187. https://doi.org/10.1080/14942119.2016.1223926
Näsärö, O.-P., Korpilahti, A., 2015: Puutavarayhdistelmien akselimassat ja kuormatilan koko. [Axle Masses and Load Space of Timber Trucks.] Metsätehon tuloskalvosarja 9/2015, 25 p. In Finnish

Orgård, O., 1998: Töva-Systemet. En berättelse om hur järnvägen övertog timmertransporterna [A Story of How the Railroad Replaced Timber Floating]. In Swedish

Palander, T., 2015: Applying Dynamic Multiple-Objective Optimization in Inter-Enterprise Collaboration to Improve the Efficiency of Energy Wood Transportation and Storage. Scand J For Res 30(4): 346-356. https://doi.org/10.1080/02827581.201 4.1001780

Palander, T., Kärhä, K., 2017: Potential Traffic Levels after Increasing the Maximum Vehicle Weight in Environmentally Efficient Transportation System: The Case of Finland. Journal of Sustainable Development of Energy, Water and Environment Systems 5(3): 417-429. https://doi.org/10.13044/j.sdewes. d5 0154

Palander, T., Voutilainen, J.J., 2013: Modelling Fuel Terminals for Supplying a Combined Heat and Power (CHP) Plant with Forest Biomass in Finland. Biosystems Engineering 114(2): 135-145. https://doi.org/10.1016/j.biosystemseng.2012.11.005

Palander, T., 2016: Environmental Benefits from improving Transportation Efficiency in Wood Procurement Systems. Transportation Research Part D: Transport and Environment 44: 211-218. https://doi.org/10.1016/j.trd.2016.03.004

Palander, T., 2017: The Environmental Emission Efficiency of Larger and Heavier Vehicles - A case study of road transportation in Finnish forest industry. Journal of Cleaner Production 155(1): 57-62. https://doi.org/10.1016/j.jclepro.2016.09.095

Palander, T., Haavikko, H., Kärhä, K., 2018: Towards Sustainable Wood Procurement in Forest Industry - The Energy Efficiency of Larger and Heavier Vehicles in Finland. Renewable and Sustainable Energy Reviews 96: 100-118. https://doi. org/10.1016/j.rser.2018.07.043

Pentti, J., 2018: Logistiikkaoperaattoripalvelun järjestäminen kotimaisen ainespuun vesikuljetuksissa. [Organizing Logistics Operator Service in Finnish Wood Barge Transportation.] Master's thesis, Lappeenranta University of Technology, 120 p. In Finnish with English summary

Petty, A., Kärhä, K., 2011: Effects of Subsidies on the Profitability of Energy Wood Production of Wood Chips from Early Thinnings in Finland. Forest Policy and Economics 13(7): 575-581. https://doi.org/10.1016/j.forpol.2011.07.003

Pirnes, V., Tuutijärvi, M.-T., Haataja, M., 2018: HCT-puutavarayhdistelmien ajoseuranta- ja stabiliteettitutkimus - Yhdistelmien liikkuvuus ja ajovakaus. [Driving Monitoring and Stability Tests of HCT-Timber Trucks - Mobility and Stability of Truck-Trailer Units.] University of Oulu, 42 p. In Finnish

Prinz, R., Väätäinen, K., Laitila, J., Sikanen, L., Asikainen, A., 2019: Analysis of Energy Efficiency of Forest Chip Supply Systems Using Discrete-Event Simulation. Applied Energy 235: 1369-1380. https://doi.org/10.1016/j.apenergy.2018.11.053

Prinz, R., 2019: Improving Performance and Energy Efficiency of Biomass Supply through Machine Alteration and Organisational Redesign. University of Eastern Finland, Faculty 
of Sciences and Forestry. Dissertationes Forestales 276: 63 p. https://doi.org/10.14214/df.276

Ranta, T., 2002: Logging Residues from Regeneration Fellings for Biofuel Production - a GIS-Based Availability and Supply Cost Analysis. Acta Universitatis Lappeenranatesis 128. Dissertation Lappeenranta University of Technology, 180 p.

Ranta, T., Korpinen, O-J., Jäppinen, E., Karttunen K., 2012: Forest Biomass Availability Analysis and Large-Scale Supply Options. Open Journal of Forestry 2(1): 33-40. http://dx.doi. org/10.4236/ojf.2012.21005

Rauch, P., Gronalt, M., 2011: The Effects of Rising Energy Costs and Transportation Mode Mix on Forest Fuel Procurement Costs. Biomass and Bioenergy 35(1): 690-699. doi:10.1016/j.biombioe.2010.10.015

Rinne, S., 2010: Energiapuun haketuksen ja murskauksen kustannukset. [The Costs of Wood Fuel Chipping and Crushing .] Master's thesis. Lappeenranta University of Technology, 102 p. In Finnish with English summary

Routa, J., Asikainen, A., Björheden, R., Laitila, J., Röser, D., 2013: Forest Energy Procurement - State of the Art in Finland and Sweden. WIREs Energy and Environment 2(6): 602-613. https://doi.org/10.1002/wene.24

Routa, J., Kolström, M., Ruotsalainen, J., Sikanen, L., 2015: Validation of Prediction Models for Estimating the Moisture Content of Small Diameter Stem Wood. Croat. j. for. eng. 36(2): 111-119.

Routa, J., Kolström, M., Ruotsalainen, J., Sikanen, L., 2016: Validation of Prediction Models for Estimating the Moisture Content of Logging Residues during Storage. Biomass and Bioenergy 94: 85-93. https://doi.org/10.1016/j.biombioe.2016.08.019

Routa, J., Kolström, M., Sikanen, L., 2018: Dry Matter Losses and their Economic Significance in Forest Energy Procurement. International Journal of Forest Engineering 29(1): 53-62. https://doi.org/10.1080/14942119.2018.1421332

Rönnqvist, M., 2003: Optimization in Forestry. Math Program 97: 267-284. https://doi.org/10.1007/s10107-003-0444-0

Röser, D., Mola-Yudego, B., Sikanen, L., Prinz, R., Gritten, D., Emer, B., Erkkilä, A., 2011: Natural Drying Treatments during Seasonal Storage of Wood for Bioenergy in Different European Locations. Biomass and Bioenergy 35(10): 4238-4247. https://doi.org/10.1016/j.biombioe.2011.07.011

Sánches-Garcia, S., Eliasson, L., Tolosana, E., Majada, J., Canga, E., 2015: Evaluation of Technological Improvements in Bundling Units for the Collection of Eucalyptus Logging Residues on Steep Terrain in Spain. Forest Systems 24(2): 8 p. http://dx.doi.org/10.5424/fs/2015242-06034

Saranen, J., 2009: Enhancing the Efficiency of Freight Transport by Using Simulation. Acta Universitatis Lappeenrantaensis 342. Dissertation, Lappeenranta University of Technology, $89 \mathrm{p}$.

Sauna-aho, J., Koskinen, O.H., Sauna-aho, P., Rivanti, T., 2018: HCT- ja normaaliajoneuvojen energiankäyttö, hiilidioksidipäästöt ja tiekuormitus. [Fuel Consumption, $\mathrm{CO}_{2}$ Emissions and Road Wear of HCT Vehicles and Standard or Normal
Vehicles in Finland.] Research reports of the Finnish Transport Agency 51/2018, 66 p. In Finnish with English summary Seppälä, P., 2019: Puun kotimaan vesitiekuljetuksen lastauspaikat. [Loading Places of Waterway Transports] Metsätehon tuloskalvosarja 10/2019, 44 slides. In Finnish

Siekkinen, A., Korpilahti, A., 2015: Rengaspaineiden säätö puutavara-ajoneuvoissa. [Central Tyre Inflation System in Timber Trucks.] Metsätehon tuloskalvosarja 13/2015. In Finnish

Shen, Z., Sessions, J., 1989: Log Truck Scheduling by Network Programming. For Prod J. 39: 47-50.

Skjäl, A., Björk, K., Östman, J., Carlsson, C., 2009: An Optimization Model for Tactical Planning of Wood Procurement. $200942^{\text {nd }}$ Hawaii International Conference on System Sciences: 1-9. https://doi.org/10.1109/HICSS.2009.69

Skogsstatistisk årsbok 2014 (Swedish Statistical Yearbook of Forestry 2014), 2014: Official Statistics of Sweden. Skogsstyrelsen, 368 p. In Swedish

Sorsa, J., 2013: Raakapuun aluskuljetuksen käyttömahdollisuudet Pielisellä. [Vessel Transportation Possibilities for Roundwood on Pielinen]. Karelia University of Applied Sciences. Thesis work, 76 p. In Finnish

Spinelli, R., Magagnotti, N., 2009: Logging Residue Bundling at the Roadside in Mountain Operations. Scandinavian Journal of Forest Research 24(2): 173-181. https://doi. org/10.1080/02827580902806593

Spinelli, R., Magagnotti, N., Picchi, G., 2012: A Supply Chain Evaluation of Slash Bundling under the Conditions of Mountain Forestry. Biomass and Bioenergy 36: 339-345. https://doi. org/10.1016/j.biombioe.2011.11.001

Spinelli, R., Ward, S.M., Owende, P.M., 2009: A Harvest and Transport Cost Model for Eucalyptus spp. Fast Growing Short Rotation Plantations. Biomass and Bioenergy 33(9): 12651270. https://doi:10.1016/j.biombioe.2009.05.010

Spinelli, R., Visser, R., Björheden, R., Röser, D., 2019: Recovering Energy Biomass in Conventional Forest Operations: a Review of Integrated Harvesting Systems. Current Forestry Reports 5(2): 90-100. https://doi.org/10.1007/s40725-01900089-0

Strandström, M., 2018a: Timber Harvesting and Long-Distance Transportation of Roundwood 2017. Metsätehon tuloskalvosarja 8b/2018, 31 p.

Strandström, M., 2018b: Metsähakkeen tuotantoketjut Suomessa vuonna 2017 [Production Chains of Forest Chips in Finland in 2017]. Metsätehon tuloskalvosarja 11/2018, 20 p. In Finnish

Swedish Energy Agency, 2019: Production of Unprocessed Primary Forest Fuels of Domestic Origin by Fuel Type, GWh, 2013.

Swedish Forest Agency, 2019: Gross Felling in 2017 and Preliminary Statistics for 2018. Skogstyrelsen, 35 p.

Swedish Transport Agency, 2018: Leagal loading. Weight and Dimension Regulations for Heavy Vehicles. Transportstyrelsen. Publication No. TS201616. 
Svenson, G., Fjeld, D., 2016: The impact of Road Geometry and Surface Roughness on Fuel Consumption of Logging Trucks. Scandinavian Journal of Forest Research 31(5): 526536. https://doi.org/10.1080/02827581.2015.1092574

Tahvanainen, T., Anttila, P., 2011: Supply Chain Cost Analysis of Long-Distance Transportation of Energy Wood in Finland. Biomass and Bioenergy 35(8): 3360-3375. https://doi. org/10.1016/j.biombioe.2010.11.014

Thorsén, Å., Björheden, R., Eliasson, L., (Eds), 2011: Efficient Forest Fuel Supply Systems. Composite report from a four year R\&D programme 2007-2010. Skogforsk., Uppsala, Sweden sid: 6-9.

Thörnqvist, T., 1985: Drying and Storage of Forest Residues for Energy Production. Biomass 7(2): 125-134. https://doi. org/10.1016/0144-4565(85)90038-1

Troche, G., 2009: Activity-Based Rail Freight Costing: a Model for Calculating Transport Costs in Different Production Systems. Trita-TEC-PHD. Stockholm, KTH. 09:002: 227.

Uotila, E., Viitala, E-J., 2000: Tietiheys metsätalouden maalla. [Road Density in Forest Lands in Finland.] Metsätieteen aikakauskirja 1/2000: 19-33. In Finnish

Uusitalo, J., 2005: A Framework for CTL Method-Based Wood Procurement Logistics. International Journal of Forest Engineering 16(2): 37-46. https://doi.org/10.1080/14942119.2005.1 0702512

Valtioneuvoston asetus 31/2019 Ajoneuvojen käytöstä tiellä annetun asetuksen muuttamisesta [The Finnish Government Regulation for Road Vehicles.]

Valtioneuvoston asetus 407/2013 Ajoneuvojen käytöstä tiellä [The Finnish Government Regulation for Road Vehicles].

Venäläinen, P., Ovaskainen, H., 2016: Terminaalitoiminnot energiatehokkaassa puutavaralogistiikassa. [Terminal Activities in Energy Efficient Timber Logistics.] Metsätehon tuloskalvosarja 5/2016, 65 p. In Finnish

Venäläinen, P., Alanne, H., Ovaskainen, H., Poikela, A., Strandström, M., 2017a: Kausivaihtelun kustannukset ja vähentämiskeinot puun toimitusketjussa. [Additional Costs of Season Variation and Mitigation Possibilities in Wood Procurement.] Metsätehon tuloskalvosarja 8/2017, 76 slides. In Finnish

Venäläinen, P., Ovaskainen, H., Hilmola, O.-P., Naukkarinen, J., Heljanko, E., Korpinen, O.-J., Aalto, M., Poikela, A., Pesonen, M., 2017b: Terminaalitoiminnot energiatehokkaassa puutavaralogistiikassa - Loppuraportti. [Terminal Activities in Energy Efficient Timber Logistics - Final report.] In Finnish

Venäläinen, P., 2018: Kotimaisen puun aluskuljetukset - yhteenveto opinnäytetöiden tuloksista. [Vessel Transports of Domestic Roundwood] Metsätehon tuloskalvosarja 9/2018, 14 slides. In Finnish

Venäläinen, P., 2019: Puutavaran ja hakkeen LHT-kuljetusselvitys. [Assessment of LHT Transport of Timber and Chips.] Metsätehon raportti 250, 31 p. In Finnish

Venäläinen, P., Poikela, A., 2019: Puutavara- ja hakeajoneuvojen massojen noston vaikutukset. [Impact of Raising Gross Vehicle Weights of Timber Trucks and Chip Trucks.] Metsätehon raportti 253, 61 p. In Finnish
Venäläinen, P., Niskanen, S., Vahtila, M., Räsänen, T., 2019: Yksityistietiedon tietolajit ja tiedonkeruumenetelmät. [Data Objects and Collection Methods of Private Road Information.] Metsätehon raportti 249, 77 p. In Finnish

Vierth, I., 2014: Summary of results, experiences and lessons learned from ELVIS demonstration project for longer and heavier trains. VTI notat; 25-2014. In Swedish

Virkkunen, M., Kari, M., Hankalin, V., Nummelin, J., 2015: Solid Biomass Fuel Terminal Concepts and a Cost Analysis of a Satellite Terminal Concept. VTT Technology 211.

Virkkunen, M., Raitila, J., Korpinen, O-J., 2016: Cost Analysis of a Satellite Terminal for Forest Fuel Supply in Finland. Scandinavian Journal of Forest Research 31(2): 175-182. https:/doi. org/10.1080/02827581.2015.1082617

von Hofsten, H., 2019: Forestry Vehicles for Transport. Arbetsrapport Skogforsk Nr. 1003, 17 p.

VR Transpoint., 2019: Kalustokuvaus (Description of Rail Cars). Available online: https://www.vrtranspoint.fi/fi/vrtranspoint/asiakkaan-opas/kalusto/rautatiekalusto/

Väätäinen, K., Anttila, P., Laitila, J., Nuutinen, Y., Asikainen, A., 2014: Aines- ja energiapuun kaukokuljetuksen tulevaisuuden haasteet ja teknologiat [Future Challenges and Technologies in Transportation of Industrial Roundwood and Energywood.] Metlan työraportteja 291, 31 p. In Finnish with English summary

Väätäinen, K., Prinz, R., Malinen, J., Laitila, J., Sikanen, L., 2017: Alternative Operation Models for Using a Feed-in Terminal as a Part of the Forest Chip Supply System for a CHP Plant. Global Change Biology Bioenergy 9(11): 1657-1673. https://doi.org/10.1111/gcbb.12463

Väätäinen, K., 2018: Developing Forest Chips Supply Chains by Redesigning Supply Operations And Logistics. University of Eastern Finland, Faculty of Sciences and Forestry. Dissertationes Forestales 250, 75 p.

Väätäinen, K., Laitila, J., Anttila, P., Kilpeläinen, A., Asikainen, A., 2020: The Influence of Gross Vehicle Weight (GVW) and Transport Distance on Timber Trucking Performance Indicators - Discrete Event Simulation Case Study in Central Finland. International Journal of Forest Engineering 31(2): 156170. https://doi.org/10.1080/14942119.2020.1757324

Wihersaari, M., 2005: Aspects on Bioenergy as a Technical Measure to Reduce Energy Related Greenhouse Gas Emissions. Doctoral dissertation. Espoo: Helsinki University of Technology, $93 \mathrm{p}$.

Wilhelmsson, L., Persson, E., Persson, T., 2005: Prognoser för virkets uttorkning efter avverkning. (Predicting the Drying Rate in Harvested Roundwood). Skogforsk Resultat 11, 4 p.

Wilhelmsson, L., Arlinger, J., Hannrup, B., Nordström, M., Øvrum, A., Gjerdrum, P., 2011: D3.5 Methods and Models for Relating Wood Properties and Storage Conditions to Process Efficiency and Product Quality. Skogforsk report 750.

Windisch, J., 2015: Process Redesign in Development of Forest Biomass Supply for Energy. University of Eastern Finland, Faculty of Sciences and Forestry. Dissertationes Forestales $189,55 \mathrm{p}$. 
Windisch, J., Väätäinen, K., Anttila, P., Nivala, M., Laitila, J., Asikainen, A., Sikanen, L., 2015: Discrete-Event Simulation of an Information-Based Raw Material Allocation Process for Increasing the Efficiency of an Energy Wood Supply Chain. Applied Energy. 149: 315-325. https://doi.org/10.1016/j.apenergy.2015.03.122

Wolfsmayr, U., Rauch, P., 2014: The Primary Forest Fuel Supply Chain: A Literature Review. Biomass and Bioenery 60: 203-221. https://doi.org/10.1016/j.biombioe.2013.10.025

Wood in energy generation, 2019: Wood in Energy Generation 2018. Statistics database, Luonnonvarakeskus. Available online: https://stat.luke.fi/en/wood-energy-generation (accessed 11 Oct 2019).

Ylitalo, E., 2018: Metsäteollisuuden puun käyttö - Forest Industries' Wood Consumption. In the book Suomen metsätilastot - Finnish Forest Statistics.; Vaahtera, E., Aarne, M., Ihalainen, A., Mäki-Simola, E., Peltola, A., Torvelainen, J., Uotila, E., Ylitalo, E., Eds.; Luonnonvarakeskus, Helsinki, Finland: 115-122.

Zamora-Cristales, R., Sessions, J., 2016: Modeling Harvest Forest Residue Collection for Bioenergy Production. Croat. j. for. eng. 37(2): 287-296.

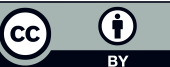

(C) 2020 by the authors. Submitted for possible open access publication under the terms and conditions of the Creative Commons Attribution (CC BY) license (http://creativecommons.org/licenses/by/4.0/).

Received: January 03, 2020

Accepted: July 31, 2020
Authors' addresses:

Senior scientist Kari Väätäinen, $\mathrm{PhD}$ *

e-mail: kari.vaatainen@luke.fi

Senior scientist Perttu Anttila, PhD

e-mail: perttu.anttila@luke.fi

Assoc prof. Juha Laitila, PhD

e-mail: juha.laitila@luke.fi

Senior scientist Robert Prinz, PhD

e-mail: robert.prinz@luke.fi

Assoc prof. Johanna Routa, PhD

e-mail: johanna.routa@luke.fi

Natural Resources Institute Finland (Luke)

Yliopistokatu 6 B

80100 Joensuu

FINLAND

Assoc prof. Lars Eliasson, PhD

e-mail: lars.eliasson@skogforsk.se

Skogforsk

Uppsala Science Park

75183 Uppsala

SWEDEN

Johanna Enström, MSc

e-mail: johanna.enstrom@skogforsk.se

Mid Sweden University

Faculty of Science, Technology and Media

85170 Sundsvall

and

Skogforsk

Uppsala Science Park

75183 Uppsala

SWEDEN

* Corresponding author 